\title{
Lessons Learned from Bacterial Transport Research at the South
}

\section{Oyster Site}

Timothy D. Scheibe, Pacific Northwest National Laboratory, P.O. Box 999, MS K9-36, Richland WA 99352, tim.scheibe@pnl.gov, Tel: 509-372-6065, Fax: 509-372-6089 (Corresponding Author)

Susan S. Hubbard, Lawrence Berkeley National Laboratory, Earth Sciences Division, 1 Cyclotron Rd., MS 90-1116, Berkeley, CA 94720, sshubbard@lbl.gov, Tel: 510-4865266, Fax: 510-486-5686

Tullis C. Onstott, Department of Geosciences, Princeton University, Guyot Hall, Princeton, NJ 08544, tullis@princeton.edu, Tel: 609-258-4141, Fax: 609-258-1274

Mary F. DeFlaun, Geosyntec Consultants, 7 Graphics Drive, Suite 106, Ewing, NJ 08626, MDeFlaun@geosyntec.com, Tel: 609-493-9005, Fax: 609-895-1401

Keywords: Bacterial transport, bioaugmentation, geomicrobiology, hydrogeophysics, modeling, heterogeneity, field research 


\begin{abstract}
This paper provides a review of bacterial transport experiments conducted by a multiinvestigator, multi-institution, multi-disciplinary team of researchers under the auspices of the U. S. Department of Energy (DOE). The experiments were conducted during the time period 1999-2001 at a field site near the town of Oyster, Virginia known as the South Oyster Site, and included four major experimental campaigns aimed at understanding and quantifying bacterial transport in the subsurface environment. Several key elements of the research are discussed here: 1) quantification of bacterial transport in physically, chemically and biologically heterogeneous aquifers, 2) evaluation of the efficacy of conventional colloid filtration theory, 3) scale effects in bacterial transport, 4) development of new methods for microbial enumeration and screening for low adhesion strains, 5) application of novel hydrogeophysical techniques for aquifer characterization, and 6) experiences regarding management of a large field research effort. Lessons learned are summarized in each of these areas. The body of literature resulting from South Oyster Site research has been widely cited and continues to influence research into the controls exerted by aquifer heterogeneity on reactive transport (including microbial transport). It also served as a model (and provided valuable experience) for subsequent and ongoing highly-instrumented field research efforts conducted by DOE-sponsored investigators.
\end{abstract}




\section{Introduction}

In 1998, the U. S. Department of Energy (DOE) established a field site near the small town of Oyster, Virginia, USA (Figure 1) to perform research on the transport of bacteria in groundwater. The research effort was focused on the concept of "bioaugmentation" - the introduction of microorganisms into an aquifer system to enhance bioremediation - and was part of a larger DOE research program called Natural and $\underline{\text { Accelerated }}$ Bloremediation $\underline{\text { Research }}$ (NABIR). The research was the outgrowth of a longer history of DOE research in subsurface microbiology and geochemistry under the Subsurface Science Program, and built upon experience and knowledge gained under a preliminary project at a nearby site as reported by DeFlaun et al. (1997; see also Mills et al., 1994; Weiss et al. 1995; Knapp et al. 1998). One of the key hypotheses of the research plan centered on the impact of groundwater redox conditions on bacterial adhesion to solid grain surfaces. Another key focus of the research was to quantify the effects of physical, chemical, and biological heterogeneity on microbial transport. Further information on the site selection process is provided below. Accordingly, two experimental plots were selected, one with fully oxygenated groundwater and ferric iron oxyhydroxides coating detrital grains (known as the Narrow Channel Focus Area or NC site) and a second with low levels of dissolved $\mathrm{O}_{2}$ and lower and more heterogeneous concentrations of ferric iron oxyhydroxides (known as the South Oyster Focus Area or SOFA site). The overall research site, containing the two experimental plots, was referred to as the South Oyster Site. The two experimental plots, which were both located in shallow, saturated sections of Atlantic Coastal Plain sediments, were highly characterized and instrumented with arrays of injection, 
extraction, and multi-level sampler (MLS) monitoring wells designed to sample continuously at low flow rates to avoid the need for purging and the resulting transient disturbance of the forced-gradient flow field (Scheibe et al., 2001; Mailloux et al, 2003b). The high level of instrumentation is evident in a field site photograph provided as Figure 2. Several forcedgradient tracer, bacterial injection, and nutrient augmentation push-pull experiments were conducted over a period of approximately four years (1999-2003) by a multi-institutional team of investigators with a wide range of disciplinary expertise. The co-Principal Investigators (coPIs) were Dr. T.C. Onstott of Princeton University and Dr. Mary DeFlaun, then of Envirogen, Inc. (currently with Geosyntec Consultants, Inc.), with primary expertise in geochemistry and microbiology, respectively. The team also included experts in geology, field and computational hydrology, hydrogeophysics, as well as other geochemists and microbiologists. Site operations and logistics were overseen by Tim Griffin (Golder Associates Inc.). Dr. Frank Wobber (DOE, Office of Science, Biological and Environmental Research) was the federal program manager leading the Bioaugmentation element of NABIR. Access to the field research site was generously granted by The Nature Conservancy, Virginia Coast Reserve. The Nature Conservancy also provided oversight of potential environmental impacts of the research, which had the benefit of giving site investigators insight into practical requirements (and public concerns) associated with bioaugmentation applications.

Figure 3 shows the physical configuration of the NC experimental plot; the configuration of the SOFA plot is similar. Preliminary site characterization data were integrated into a suite of numerical models that were used to perform "pre-modeling" for the purpose of designing well configurations and injection strategies (Scheibe et al., 2001). The models were in part 
parameterized based on intact column experiments and outcrop studies conducted at a nearby borrow pit (Fuller et al., 2000; Dong et al., 2002a, 2002c). Several major experimental campaigns were conducted at the two flow cells, as summarized in Table 1. Balkwill et al. (2001) provide an overview of site characteristics, experiments conducted, and results. 
Table 1. Summary of major experimental campaigns conducted at the South Oyster Site.

\begin{tabular}{|l|c|c|c|}
\hline Year & Dates & Flow Cell & Emphasis \\
\hline $\mathbf{1 9 9 9}$ & $\begin{array}{c}\text { Jul- } \\
\text { Aug 1999 }\end{array}$ & NC & $\begin{array}{c}\text { Bromide tracer (delineate flow paths and travel } \\
\text { times), develop and test groundwater sampling methods, } \\
\text { evaluate flow cell design }\end{array}$ \\
\hline $\mathbf{1 9 9 9}$ & $\begin{array}{c}\text { Oct- } \\
\text { Nov 1999 }\end{array}$ & NC & $\begin{array}{c}\text { Bromide and DA001 (adhesion-deficient strain) } \\
\text { bacterial injection under oxic conditions }\end{array}$ \\
\hline $\mathbf{2 0 0 0}$ & $\begin{array}{c}\text { Jul- } \\
\text { Aug 2000 }\end{array}$ & SOFA & $\begin{array}{c}\text { Bromide, DA001, and OY-107 (iron-reducing bacteria) } \\
\text { coinjection under hypoxic conditions }\end{array}$ \\
\hline $\mathbf{2 0 0 1}$ & $\begin{array}{c}\text { Jul } \\
2001\end{array}$ & SOFA & $\begin{array}{c}\text { Bromide, DA001, and OY-107 injection into separate } \\
\text { injection wells }\end{array}$ \\
\hline $\mathbf{2 0 0 1}$ & $\begin{array}{c}\text { Aug } \\
2001\end{array}$ & SOFA & \begin{tabular}{c} 
Biostimulation experiment (push-pull tests) \\
\hline
\end{tabular} \\
\hline
\end{tabular}

The focus of South Oyster Site activities was on bacterial transport processes, but also provided opportunities for a broad range of research studies in related areas and the results of research related to the site have been published in at least 60 peer-reviewed journal articles (Table 2). This review provides an overview of "Lessons Learned" across this range of studies; we refer the reader to previously published articles for further details on particular aspects.

\section{Bacterial Transport Processes}

Ginn et al. (2002) provides a comprehensive review and discussion of microbial transport processes and includes selected results from the South Oyster Site as a case study. The process that exerts the greatest influence on subsurface microbial transport is attachment to mineral grain surfaces, which partitions bacteria between the mobile aqueous phase and the immobile attached phase. Microbial attachment is most often represented using Colloid Filtration Theory 
(CFT), which includes interception, diffusion, and sedimentation as physical processes resulting in physical contact of a colloid with a mineral surface. In conventional CFT, colloids and grain surfaces are assumed to have strong attractive charges that result in a primary energy minimum that permanently traps colloids coming into contact with the grain surface. Under CFT, the kinetic rate of attachment is posited as:

$$
\frac{\partial C}{\partial t}=-\left[\frac{3}{2} \frac{(1-\theta)}{d_{g}} \eta V\right] C
$$

where $C$ is the aqueous concentration of microbes, $\theta$ is porosity, $d_{g}$ is an effective grain diameter, $V$ is the magnitude of groundwater flow velocity, and $\eta$ is the "collector efficiency", defined as the probability that a colloid approaching a grain surface will come into physical contact with the surface. Logan et al. (1995) provide a useful summary and clarification of theoretical analytical expressions for $\eta$, and Nelson and Ginn (2001) give a summary of major assumptions and implications of CFT as applied to bacterial transport in porous media.

Many microorganisms have negatively charged membrane surfaces. The surfaces of quartz grains that comprise many sandy aquifers are also negatively charged under ionic strength and $\mathrm{pH}$ conditions typical of near-surface groundwaters creating unfavorable conditions for attachment since similarly-charged surfaces exert repulsive forces, whereas iron oxides that coat some sedimentary grains are dominantly positively charged creating favorable conditions since opposite charges create attractive forces. Therefore, a mixture of favorable and unfavorable conditions for microbial attachment may exist in many sandy aquifers like that at 
the South Oyster Site. At surfaces where an energy barrier to deposition exists, there often exists a secondary energy minimum farther from the grain surface in which negatively-charged colloids can become trapped, but from which they can also be more readily dislodged by hydrodynamic or other forces. These factors lead to two common modifications of CFT required for representing microbial attachment: 1) incorporation of a "collision efficiency" factor, $\alpha$, which represents the probability that collision between a microbe and a mineral surface will result in attachment, and 2) incorporation of a detachment rate to represent dislodgement of microbes from secondary minimum attachment sites. Neither of these terms is required in traditional CFT applications (such as engineered sand bed filters) in which conditions are uniformly favorable for attachment in a primary minimum. However, since there is a mixture of favorable and unfavorable attachment conditions in natural systems, these additional terms are needed to maintain the integrity of the CFT model while still matching observations. The modified CFT attachment rate for microorganisms is then represented as:

$$
\frac{\partial C}{\partial t}=-\left[\frac{3}{2} \frac{(1-\theta)}{d_{g}} \eta \alpha V\right] C+K_{d} S
$$

where $K_{d}$ is the detachment rate coefficient and $S$ is the concentration of attached-phase bacteria. In this conceptualization, the collector efficiency $\eta$ depends only on measurable physical properties of the fluid, porous medium and microorganism and can be directly predicted using CFT theory. $\alpha$ and $K_{d}$, however, depend jointly on electrochemical properties of the cell membrane, extracellular structures and mineral surfaces as well as hydrodynamic forces and are difficult to predict theoretically. Dong et al. (2002b) present a quantitative 
framework for predicting $\alpha$, but the same author also points out limitations in the applicability of the underlying theory (Dong, 2002). Because of these difficulties, $\alpha$ and $K_{d}$ are typically estimated from experimental observations by model fitting.

It has been commonly observed in many column and field studies that such estimates of $\alpha$ vary systematically with spatial scale, with the largest values observed at short distances from the injection point. However, no single consistent theory exists to explain this apparent scale dependency. At the NC flow cell, Mailloux et al. (2003a) estimated a field-scale distribution of apparent values of $\alpha$ from breakthrough observations at varying distances. The estimated values clearly decreased with transport distance and the distribution inferred from column experiments (short transport distances) was shown to correspond to the highest values (shortest distances) observed in the field. Since microbial populations, even of a single species, exhibit variability in surface membrane charge (e.g., Dong, 2002), this observation has been attributed by most investigators (e.g., Bolster et al., 2000) to selective removal of "more sticky" (large $\alpha$ ) members of the population near the injection point followed by more efficient transport of "less sticky" (small $\alpha$ ) members at longer transport distances. Dong et al. (2006) report on a novel side experiment conducted during the 2001 SOFA microbial injection experiment to test this hypothesis. Groundwater samples containing bacteria extracted from monitoring wells at different distances from the injection point were immediately injected into repacked sediment columns set up at the field site to determine whether the bacteria that had traveled longer distances exhibited significantly lower collision efficiencies in the columns. Surprisingly, the populations extracted from wells with longer travel distances exhibited larger 
values of $\alpha$ when transported through the columns, although model interpretation of the field observations indicated the familiar decrease of $\alpha$ with transport distance. They explained this apparent contradiction as resulting from a combination of microbial charge variability and spatially correlated physical and chemical aquifer properties (discussed further below).

Another interesting apparent discrepancy between column-scale and field-scale observations relates to the process of size exclusion. The typical size of bacteria $(\sim 1 \mu \mathrm{m})$ is large enough that they can be physically excluded from regions of the pore space where flow velocities are smallest (i.e., very close to grain surfaces or in dead-end micropores). As a result, the average velocities experienced by biocolloids can in some cases be larger than that of molecular solutes such that bacterial breakthrough can significantly precede that of a conservative solute tracer. This effect may be accentuated by charge exclusion (also called ion exclusion) in which negatively-charged bacteria can be electrically repulsed away from negatively-charged mineral surfaces, again limiting access to the lowest-velocity regions immediately adjacent to the solid grains (no-slip flow boundary condition). In column experiments conducted using intact sediment samples collected from the nearby borrow pit, significantly higher bacterial velocities were observed relative to conservative tracers (ratios ranging from 1.18 to 1.55 as reported by Dong et al. (2002c). Scheibe and Wood (2003) developed a new particle tracking algorithm to simulate the exclusion process in the column studies, based on truncation of the distribution of dispersive displacements in the random walk algorithm. Size exclusion processes, however, were not evident in the results of the field experiments, in which most bacterial breakthrough curves could be adequately modeled using 
the same average velocity as the tracer. The reason for this discrepancy between column and field scale studies is unclear.

Another factor that appeared to play a role in bacterial transport at the South Oyster Site was predation on bacterial cells by protozoan populations pre-existing in the aquifer system. A "bloom" of protozoans (particularly flagellates) was observed in all of the multi-level samplers during the 1999 NC injection experiment (Zhang et al. 2001). The increase in protozoan populations lasted approximately 10 days and peaked 7-10 days after the peak of injected bacteria. Because the timing of the peak corresponded closely to the injection, and since the bacteria were injected using site groundwater with no nutrient amendments, the peak in protozoan populations can be attributed to increased growth associated with predation on the injected bacteria. Careful analysis of late-time observations of bacterial concentrations by Zhang et al. (2001) strongly suggest that predation of injected bacteria by protozoans (rather than increased attachment) led to the observed decrease in bacterial concentrations following the end of the forced-gradient phase of the experiment.

\section{Shortcomings of CFT for Quantifying Bacterial Transport Processes}

CFT has been applied successfully to clean bed filtration of colloidal materials in engineered filtration systems. Its adaptation to modeling of microbial transport in aquifers was pioneered by Harvey and Garabedian (1991) as a very reasonable extension given the colloidal size of microorganisms. Critical differences exist between microbes in natural aquifers and nonbiological colloids in engineered filters that lead to now well-known limitations in the 
application of CFT to microbial transport. These have been widely discussed in the literature and are well summarized by Ginn et al. (2002) and other reviews, so will not be described in detail here. We will discuss, however, certain aspects of the South Oyster Site experiments and models that provided critical evidence that informs these issues.

Because attachment of microorganisms in natural porous media often occurs under unfavorable conditions (that is, the lack of a strong primary energy minimum and microbial association with a weak secondary energy minimum), one key difference between classical CFT and microbial applications is the process of detachment (which is not considered in classical CFT). Because of the high-resolution methods of cell enumeration used (and in some cases developed) by South Oyster Site investigators (e.g., Zhang et al., 1999; Fuller et al., 2000b; Johnson et al., 2001), it was possible to observe injected cells in the experimental flow cells at very low concentrations and relatively long transport distances. Zhang et al. (2001) performed model interpretations of extended tailing (four months) of bacterial breakthrough at the NC focus area to infer attachment and detachment rate coefficients. They then performed comparative simulations with and without detachment and concluded that even the relatively low rates of detachment commonly observed for microbes may significantly increase the extent of transport under field conditions. Microbial processes may also come into play in the detachment process, in that loosely attached cells could grow extracellular structures that would enhance adhesion and lead to irreversible attachment. Alternatively, cells trapped in a secondary minimum might translate along a grain surface under hydrodynamic forces to a location (such as a flow stagnation zone or grain-to-grain contact) where they could become more permanently trapped. Improvement between model predictions and field observations 
was achieved when a parameter describing the relative fraction of reversible and irreversible attachment events (Zhang et al., 2001), as well as a time-dependent irreversibility process (e.g., Johnson et al. 1995), was included. The South Oyster Site project modeling team developed a novel particle tracking model approach (Zhang et al., 2001; Scheibe and Wood, 2003; Li et al., 2004) that facilitated implementation of these and other novel process representations in numerical simulations.

Another significant difference between microorganisms and inorganic colloids is that microbes can exhibit active motility (swimming) and chemotaxis (attraction to chemical gradients). Although the selected organisms used in South Oyster Site experiments were thought to be non-motile, project investigators performed a theoretical study of chemotactic motility by developing a novel particle-tracking approach applied to the Happel sphere-in-cell model on which CFT theory is based (Nelson and Ginn, 2001). Preliminary results from their simulations suggested that bacterial chemotaxis could significantly impact the value of the collector efficiency $(\eta)$ under certain conditions.

Prior to the South Oyster Site project, most investigations of microbial transport at the column scale had fitted models based primarily on observations of column effluent concentrations over time assuming microbial mass balance and no microbial growth. South Oyster Site investigators addressed this issue by extracting attached cells from column sediments at the end of the experiment in order to quantify the profile of attached microbial concentrations along the columns (Fuller et al., 2000a). Although obtaining sufficient recovery to close the mass balance on injected cells proved challenging, the data obtained provided an alternative window into the bacterial attachment process that proved extremely valuable. For 
most column experiments, the effluent curves could be reasonably matched using a simple linear kinetic attachment/detachment rate model (based on the modified CFT theory). The profiles of attached bacteria predicted by this model, however, did not match those observed in the column experiments. The predicted concentration profiles under the standard model were log-linear in form, whereas the observed concentration profiles typically showed much higher than expected concentrations of attached bacteria near the column inlet, and exponential decay of concentrations along the profile. This observation was explored in detail by Li et al. (2004), who concluded that apparent decreases in attachment rate coefficients with distance (observed for inorganic and biological colloids) reflect processes that are fundamental to filtration under unfavorable conditions. They observed that deviations in the attached profile from the predicted log-linear profile were largest under strongly unfavorable conditions and were eliminated under favorable attachment conditions. They also demonstrated that variation in interaction potentials (surface charge) within the colloid populations provided a viable mechanism to explain the apparent decrease in deposition rate with transport distance.

Subsequent investigators have posed other possible mechanisms that could also explain these observations, such as enhanced straining near the column inlet (Bradford et al, 2006) or grain surface charge heterogeneity (Johnson et al., 1996). The fact that multiple alternative models with significantly different process conceptualizations could fit the column-scale observations equally well underlines the potential danger of inferring validity of assumed process models from their ability to be fitted to limited observations. Interestingly, this situation has motivated a new line of ongoing research based on pore-scale simulation and observation of colloidal transport (Li et al., 2006; Johnson et al., 2007; Torkzaban et al, 2008; Li 
et al., 2010a; Li et al., 2010b; Gao et al., 2010) that holds promise for elucidating the actual mechanisms that are responsible for the observed phenomena. Combining observations of bacterial break-through with profiles in adsorbed bacteria at the field scale, however, has yet to be accomplished and will be critical to scaling up from the pore-scale to kilometer scale.

\section{Impacts of Physical, Chemical and Microbial Heterogeneity}

The term "microbial heterogeneity" is used in two distinct contexts within the South Oyster Site project literature. In one context, it is used to describe spatial variations in microbial number density within the aquifer materials. Brockman and Murray (1997a, 1997b) provided some of the earliest information on techniques for characterizing subsurface microbial heterogeneity. Their review articles, based in part on analysis and comparison of data from the Oyster site and the White Bluffs site in eastern Washington, provide a discussion of potential causes of variation in bacterial number density and of geostatistical approaches that can be used to characterize it. Zhang et al. (1998) reported studies from the Oyster excavation and found that microbial concentrations varied only by about 15 -fold over sampling distances as short as $5 \mathrm{~cm}$ and were not correlated to grain size, probably because of the relatively small range of grain size variations at the site. The variations were correlated with natural organic matter content, which varied in turn with depth from the surface. Musselwhite et al. (2003; 2007) also evaluated microbial heterogeneity in Oyster sediments, with a focus on the metabolic activity of sulfate-reducing bacteria. They also found relatively small variations in microbial properties and poor correlations with sediment properties. Although spatial 
variability of initial cell counts may impact active bioremediation efforts (Pfiffner et al, 2001), the low variability in microbial counts and activity observed at Oyster is unlikely to have had significant impact on the transport of injected bacteria. The term "microbial heterogeneity" is also used (e.g., Mailloux et al., 2003a) in reference to variations in cell properties within a monoclonal culture. Greatest attention in this regard is given to variations in cell surface charge, as measured by electrophoretic mobility (Dong, 2002), which is expected to directly impact the $\alpha$ parameter in CFT-based models. Mailloux et al. (2003a) defined a distribution of $\alpha$ values by model fitting to bacterial transport observations from the NC focus area, and concluded that variations in microbial properties exerted greater control on the magnitude of bacterial attachment than physical aquifer properties, although the specific paths followed by the bacteria in the subsurface corresponded to zones of higher permeability. Although that work downplayed the impact of physical heterogeneity on microbial attachment, transport experiments conducted in intact sediment columns by Dong et al. (2002a) indicated that bacterial adhesion was predominantly controlled by grain size variations. Hall et al. (2005) conducted another series of short column experiments, this time using groundwater collected from the oxic NC site and the hypoxic SOFA site, again in an attempt to elucidate physical and chemical impacts on microbial transport. They concluded that the different geochemical conditions existing at the two sites led to differing controls on transport. For SOFA site groundwater, with low dissolved $\mathrm{O}_{2}$ and organic carbon (DOC), attachment was predominantly controlled by prevalence of metal oxide surfaces. For NC groundwater (relatively high $\mathrm{O}_{2}$ and DOC), however, the metal oxide surfaces appeared to be masked by sorbed DOC, thus leading to predominant control of grain size on observed attachment rates. 
The apparent contradictions in the conclusions of these various studies, each aimed at separating out the effects of physical, chemical, and microbiological heterogeneity, point to the need to consider their joint effects under a range of possible conditions. Ensuing studies demonstrated that it is likely the combined effects of spatially correlated physical, chemical and microbial heterogeneity (rather than the individual effect of any one type of heterogeneity) that controls key aspects of microbial transport behavior. The paradoxical experimental results obtained by Dong et al. (2006), in which $\alpha$ values measured using bacteria extracted from wells at different distances from the injection well were observed to increase with distance traveled (not decrease as expected), were interpreted by those authors to reflect the effect of correlated physical and chemical heterogeneity combined with variations in microbial cell surface properties. At the South Oyster Site, the highest concentrations of iron oxide grain coatings tend to occur in the finest-grained (lowest permeability) sediments. Bacteria are more readily transported in the field through the coarser-grained clean quartz sand layers, and the negative charge of the quartz surfaces favors transport of more negatively charged cells. When injected subsequently into a homogenized sediment column, the cells with strong negative charge are forced to interact with fine grains coated with positively charged iron oxides and thus exhibit strong attachment. This interpretation was subsequently tested numerically by Scheibe et al. (2007). They performed simulations of microbial transport based on South Oyster Site field data under a variety of assumptions regarding the nature of physical (hydraulic conductivity) and chemical (attachment rate coefficient) heterogeneity, and demonstrated that the familiar apparent decrease in $\alpha$ with transport distance was predicted only when hydraulic conductivity and attachment rate coefficient parameters were inversely correlated. Such 
correlation arises naturally from the joint dependence of collision efficiency and hydraulic conductivity on grain size, and this effect would be enhanced by relatively higher concentrations of iron oxides (preferred attachment sites) in fine-grained sediments and variations in microbial cell surface charge. The negative correlation between iron oxide concentrations and hydraulic conductivity at the field scale was inferred by statistical analysis of South Oyster Site borehole and geophysical data by Chen et al. (2004). The existence of a similar negative correlation at the column scale was demonstrated by Dong et al. (2002a). Scheibe et al. (2006) used the results of Chen et al. (2004) to numerically simulate a hypothetical bioremediation scenario and demonstrated that the joint effects of correlated physical and chemical heterogeneity significantly impact the predicted efficiency of bioremediation. Because reaction processes (including metal reduction and microbial attachment) require close physical proximity of reactants, the coupling between physical flow, solute transport and chemical reactions leads to emergent behaviors that are not evident from independent consideration of physical, biological, and chemical properties and processes.

\section{Site Characterization}

The surficial unconfined aquifer underlying the Oyster Site is located in the Wachapreague Formation (Mixon, 1985) and consists primarily of medium to coarse sands deposited in a marine shoreface environment (Parsons et al., 2003). A pervasive fine-grained layer (clay-rich silt) encountered at approximately 10 meters depth serves as the lower boundary of the surficial aquifer; the depth to water table is approximately 2 meters. 
A wide variety of site characterization data was collected, including geophysical observations (surface ground-penetrating radar, radar tomography, and seismic tomography); hydrologic aquifer tests (pumping and slug tests, borehole flowmeter tests); borehole core logs and analyses (visual and quantitative grain size distribution, facies type, permeability on subcore samples); air mini-permeameter and photographic and infrared imaging on analog sediments from a nearby excavation face; long-term, continuous monitoring of water level and quality; cone penetrometer observations (tip and sleeve stress, pore-water pressure); and groundwater and soil chemistry analyses of selected samples. In addition, intact core samples were collected from a nearby excavation and were used for laboratory tracer and bacterial transport experiments to estimate bacterial transport parameters (Fuller et al. 2000a). These characterization efforts resulted in a rich data set that provided a sound foundation for the broad range of experimental research conducted at the site, and interpretation / integration of the experimental results through numerical modeling.

The first role of site characterization was in support of detailed site selection. Traditional surface GPR imaging was conducted along transects spanning the target area to develop a conceptual model of large-scale site stratigraphy and to identify specific areas for more detailed study (Hubbard et al., 2001). Cone penetrometer tests were used to confirm that required geochemical conditions existed in the two flow cells (oxic - NC - and hypoxic - SOFA) and to define the extent of the hypoxic zone at the SOFA flow cell.

Once the two focus area sites were identified, a suite of wells were emplaced using the layout employed successfully in the preliminary experiments of DeFlaun et al. (1997). These included eight wells that could potentially be used for pumping to control hydraulic gradients 
during experiments, a single injection well, and other wells outside the flow cell to monitor background conditions and to monitor for potential escape of injectates from the flow cell.

The initial integration of these data into a quantitative field-scale transport model and use of that model for experimental design is presented by Scheibe et al. (2001). Those simulations were based primarily on electromagnetic borehole flowmeter measurements of hydraulic conductivity in boreholes (which provide high vertical resolution), with horizontal correlation lengths based on interpretations of cross-borehole ground-penetrating radar analyses given by Hubbard et al. (1999; 2001). The design simulations were used to develop a layout for twentyfour multi-level sampling wells (MLS) and define injection/extraction rates and concentrations, and preliminary sampling schedules (to be adapted in the field based on real-time measurements). The initial experiments based on the developed design were conducted successfully. Scheibe et al. (2001) attribute this successful effort to the following attributes of the design process: “1) integration of quantitative input from a linked set of numerical flow and transport models with detailed characterization data and qualitative judgment of an interdisciplinary research team, 2) iterative updating of predictive models and the resulting experimental designs based on staged data collection, and 3) real-time field adjustment of sampling schedules based on field-deployable analytical equipment."

The use of a variety of high-resolution, multi-dimensional hydrogeophysical methods was a critical element of South Oyster Site research. Hydrogeophysics, the application of geophysical methods to near-surface hydrogeological problems, is a relatively new discipline, as reflected in the formation of the Hydrogeophysics Technical Group within the American Geophysical Union in 2003 and the publication of the first textbook on the field in 2005 (Rubin and Hubbard, 
2005). Many hydrogeophysical methodologies were developed and tested using datasets acquired at the South Oyster Site. Examples include the use of geophysical data to estimate: soil water content (Hubbard et al, 1997a), hydraulic conductivity (Hubbard and Rubin, 2000; Hubbard et al., 2001; Chen et al., 2001), hydraulic conductivity spatial correlation parameters (Hubbard et al., 2001), lithofacies (Chen and Rubin, 2003; Linde et al., 2008), mean flow velocity and injectate plume spatial moments (Hubbard et al., 2001), and sediment geochemistry (Chen et al., 2004).

Hydrogeophysical studies at the South Oyster Site permitted the development of methodologies as well as insights about near surface systems. The datasets enabled exploration of the value of multiple types of geophysical data for quantifying hydrological parameters (Chen et al., 2001) and permitted comparison of different hydrogeophysical integration approaches (Linde et al., 2006a). The studies illustrated the great control that heterogeneity has on injectate distribution, even in 'mildly heterogeneous' environments such as South Oyster. The studies also illustrated that integration of wellbore hydrological measurements (particularly flowmeter data) and geophysical datasets (particularly tomographic radar data) provided information about hydraulic conductivity variations at a reasonable scale and resolution for understanding field-scale flow and transport processes. For example, Figure 4a illustrates the estimates of mean hydraulic conductivity values (along the flowcell centerline shown in Figure 3b) obtained using a Bayesian approach, which involved integration of crosshole tomographic radar velocity values with wellbore flowmeter hydraulic conductivity information. Superimposed on the hydraulic conductivity profile is the trajectory of the bromide tracer plume centroid over time, which was calculated from the breakthrough data 
following Hubbard et al. (2001). Figure 4b illustrates a comparison of the measured bromide breakthrough at a single multi-level sampling well along that transect compared to breakthrough realizations simulated using an aquifer heterogeneity conditioned to the geophysical estimates (from Scheibe et al., 2001). The joint analysis of measured field data with hydrogeophysical and numerical simulation approaches allowed us to gain a better understanding of subsurface flow and transport processes in the presence of heterogeneity and also allowed us to explore the value of combining multiple approaches to interrogate subsurface systems. The geophysical studies at the South Oyster Site also served as a prelude to subsequent studies, which also illustrated the great control of heterogeneity on bioremediation efficacy (Hubbard et al., 2008) as well as the use of geophysical methods for quantifying microbially-induced transformations in-situ, a field now known as biogeophysics (Atekwana et al., 2009; Williams et al., 2009).

The availability of large numbers and a variety of types of data at the Oyster Site also provided a unique opportunity to quantitatively evaluate the relative value of the hydrogeophysical data as conditioning information constraining numerical predictions of solute transport during tracer experiments. Such an analysis is presented in Scheibe and Chien (2003), who compared simulated and observed tracer breakthrough curves at 140 sampling points in the three-dimensional MLS sampling array at the NC flow cell. They performed six sets of simulations with variable degrees of model complexity and informed by different types of characterization data, including 211 direct hydraulic conductivity measurements using close vertical spacing using borehole flowmeters and cross-sectional estimates of hydraulic conductivity based on interpretation of cross-borehole ground-penetrating radar. Some of the 
simulations were deterministic in nature, while others generated suites of stochastic realizations with an associated range of predicted breakthrough curves. The results demonstrated that conditioning predictions to borehole flowmeter measurements alone (which are local in scale and provide resolution only in the vertical dimension) did not significantly improve model predictions, and appear to have led to biased and overly confident predictions. On the other hand, addition of the geophysical data (which provides horizontal as well as vertical resolution and has greater spatial extent of coverage) significantly improved both the accuracy and precision (estimated degree of uncertainty) of the model predictions. The importance of this result is reflected in the fact that subsequent works have referenced this study as being the first clear demonstration of the quantitative value of hydrogeophysical methods for flow and transport modeling (e.g., Rubin and Hubbard, 2005; Linde et al, 2006b; Hubbard et al., 2008; Hubbard and Linde, 2010).

\section{Microbiological methods}

The South Oyster Site experiments provided an opportunity for development and testing of a wide range of microbiological experimental methods. In this section we provide a brief review of some interesting and novel methods used in South Oyster Site experiments.

Because the focus of the experiments was on bacterial transport for purposes of bioaugmentation, there was motivation to maximize the degree of transport of injected bacteria. A number of organisms were cultured from the site groundwater and screened for key characteristics (specified largely by the landowner and local public) resulting in 
identification of a Comomonas species that met project requirements. An adhesion-deficient sub-population of this strain was selected by repeated passage of the culture though minicolumns constructed in $20-\mathrm{mL}$ syringes packed with sterile sand. The columns were initially drained of excess fluid and then rinsed after one hour; the cells that were collected in the rinsate were then again cultured and reinjected into another sand column. The cells that appeared in the column effluent were then again cultured and reinjected into a sediment column. This process was repeated multiple times until a subpopulation with adhesion deficiency was isolated. The enhanced transport of this subpopulation was then compared to that of the wild-type culture in both repacked and intact cores of South Oyster Site sediment (DeFlaun et al., 1999). This work demonstrated the effectiveness of developing an adhesiondeficient strain through selective enhancement of a sub-population.

Quantifying the transport of bacteria by injection experiments required accurate and precise means of enumerating bacteria in water samples collected at monitoring wells. A suite of methods were developed and tested by comparison to one another during using a bacterial injection experiment conducted in an intact core as reported in DeFlaun et al. (2001). The methods considered were selected and developed to meet the following criteria: 1) ability to distinguish from non-injected bacteria of the same strain (since these bacteria were isolated from the experimental site), 2) no impact on viability or transport behavior of the strain, 3) low detection limits, 4) a large quantification range (several orders of magnitude of concentration), and 5) reasonable analytical cost and time. Methods employed at the South Oyster Site and compared in this experiment included quantitative $\mathrm{PCR}$, enumeration of ${ }^{13} \mathrm{C}$-enriched bacteria using combustion-IRMS (Holben and Ostrom, 2000; Lytle et al., 2001), and enumeration of 
bacteria labeled with a vital fluorescent stain (Fuller et al., 2000b) using microplate spectrofluorometry, flow cytometry, and a ferrographic method (Johnson et al., 2001). These methods were compared with each other and with more traditional methods (plate counts and direct microscopic enumeration). The developed methods compared favorably with one another and with direct counts. Combustion IRMS and ferrographic enumeration had the lowest quantification limits, with the capability of quantifying as few as 2 to 20 cells per milliliter of groundwater. Because the intensity of the fluorescent stain (as tracked with a flow cytometer) decreased systematically as cells divided, Mailloux and Fuller (2003) were able to estimate in situ growth rates for two strains of injected bacteria.

\section{Practical Elements of Managing a Large Field Investigation}

The South Oyster Site research effort was a multi-investigator, multi-institution, multidisciplinary project that required a high degree of integration for success. Coordination of the project was accomplished primarily through 1) regular (often weekly) conference calls, 2) sharing of data and information through a project website and other electronic means, 3) annual stocktaking and review meetings, and 4) broad participation in field experiments.

Early in the project, we found ourselves repeatedly discussing issues on conference calls that had been previously discussed. Although in many cases a decision had previously been made, the rationale for the decision (and sometimes the decision itself) had become unclear by the next time it was discussed. It became obvious that a mechanism for documenting project decisions and their rationale was sorely needed. A section of the project website (accessible by 
password to project participants and approved guests) was developed for this purpose, referred to as the "Experimental Design Process." A main page was developed for each major field campaign, and contained a table with each of the high-level elements of the subject campaign (e.g., "Initial Site Characterization", "Install Flow Cell”, "Cross-Borehole Tomography", "Install Multi-Level Samplers" and the like). For each high-level element, a design chart was constructed that contained a record of the key considerations, participants in the decision process, characterization needs, prerequisites for design and implementation, and schedule/milestones. These pages, updated in real time during conference calls, served as the collective "memory" of the project investigators and served to provide clear documentation of planning decisions throughout the process. The project website was also used extensively for sharing data, draft manuscripts, relevant literature, etc. A centralized point for data sharing helped to ensure that all analyses were conducted using the latest data and that all investigators had timely access to needed information. Selected portions of the website were made accessible to the public and used to inform local residents, the landowner, and other interested parties of project schedules and outcomes.

Stocktaking meetings were held on at least an annual basis, initated and led by the DOE Program Manager, Dr. Frank Wobber and project investigators. Guest scientists (not directly involved in the project) served as reviewers and provided comments and input to the project team. In some cases, their participation also led to new collaborations as fresh ideas were brought into the meetings. The stocktaking meetings project investigators to collaborate effectively and remain aware of the entire breadth of site-related research. DOE and principal investigators expected strong integration among the various participants; this was required for 
the success of both individuals and the project as a whole. One of the challenges of communicating results of large multi-investigator projects is avoiding unreasonable overlap between publications and maintaining proper authorship attribution, especially for PhD. students and postdoctoral research associates. A spreadsheet of publications at various stages of development (published, in press, in review, in preparation, planned) was developed and maintained as a central resource. At each stocktaking meeting the spreadsheet was updated to ensure that everyone was aware of others' plans for publications and was provided opportunities to participate as appropriate. The spreadsheet was frequently revisited during conference calls between stocktaking meetings to track progress and update the listing.

In addition to conference calls and stocktaking meetings, regular participation by the broad project team in field activities served an essential role in developing collaborative relationships and ensuring effective integration. In many large projects, scientists with different focal points (e.g, laboratory researchers, numerical modelers) tend not to participate actively in field activities. The temptation to let collaboration take the form of "tossing data over the fence" between researchers with varying focus and different disciplinary backgrounds, without active participation in one anothers' efforts, can be strong. At the South Oyster Site, all project participants agreed to participate in field activities, which led to a much higher level of project integration than would have otherwise occurred. Although it may sound clichéd, spending time in the field together (often under less than comfortable conditions with biting insects, adverse weather, and midnight shifts) did in fact help to develop a sense of camaraderie among the project team. It also provided extended times in which ideas and information could be shared, and deeper understanding of aspects of the project outside one's own area of interest could be 
developed. Most importantly, it provided a very real avenue for iterative feedback between experimental, theoretical, and numerical elements of the project.

It is interesting to note that the initial project proposal did not include a numerical modeling element; this was incorporated subsequently as a result of specific reviewer comments. However, despite this initial oversight (and perhaps skepticism about the value of numerical modeling in such a project), the numerical modeling effort eventually became widely accepted as a central integrating element of the research. Numerical modeling (and the associated data analyses) provided a platform for integration of diverse data types, was used to guide experimentation including development of detailed sampling plans (pre-modeling), and supported interpretation of experimental results (post-modeling). By working side by side in the field, experimentalists were able to observe firsthand the usefulness and limitations of numerical models, and modelers gained a strong appreciation for the experimental processes underlying the data that they need to develop and execute simulations. Finally, field experimentation provided an excellent opportunity for high quality student experiences. Many students (both undergraduates and graduate students, and in one case a high school student) participated actively in the field research activities. Their energy and enthusiasm was infectious, and without a doubt the experiences gained by students were among the most memorable of their academic careers.

In order to maximize awareness and impact of South Oyster Site research activities, strong efforts were made to engage the broader scientific community. In addition to inviting external scientists to stocktaking meetings, project investigators also convened special sessions at a number of conferences and developed a high-level summary of project activities and results for 
publication in EOS, the weekly newspaper sent to the membership of the American Geophysical Union (Balkwill et al., 2001).

\section{Conclusions}

A significant body of research was performed by a multidisciplinary research team focused on the South Oyster Site. The development of a highly instrumented and characterized research field site catalyzed an impactful research program with broad scope. Some of the many important "lessons learned" have been discussed above and are summarized here.

Impacts of Heterogeneity: Much effort was invested in trying to identify the independent effects of physical, chemical, and biological heterogeneity. In the end, it became clear that no single aspect of heterogeneity was individually dominant, but rather it is the combined (joint) nature of multiple types of heterogeneity that controls microbial transport. Because of the dependence of both hydraulic conductivity and attachment rate on grain size, a natural inverse relationship emerges between the two that can in part explain the apparent scale dependence of attachment rate with transport distance. The concentration, spatial distribution, and chemical state of iron oxide grain coatings strongly influences microbial transport at field and laboratory scales, and is also often correlated with grain size (and thus hydraulic conductivity). Significant variations in cell surface properties (surface charge) were observed within a single microbial population and were shown to play a role in the apparent scale-dependence of attachment rate. 
Microbiological Methods: An adhesion-deficient sub-population of a single microbial strain was isolated by selective culturing. This is important for bioaugmentation in that it increases the distance over which microorganisms can be successfully transported from an injection point. New and previously existing microbial tracking methods were successfully implemented and provided an accurate basis for measurement of quite low concentrations of injected bacteria.

Microbial Transport Processes: Column studies performed in support of the field research were among the first to quantify the distribution of attached microbes along the column length following transport experiments. This additional information (supplementing aqueous breakthrough data) provided significant new insights into the nature of microbial attachment processes and clearly demonstrated shortcomings of CFT. This has motivated a substantial body of research aimed at identifying mechanisms responsible for the observed exponential concentration profiles. New numerical models were developed to incorporate chemotaxis into the filtration theory framework and to simulate size exclusion, multi-rate attachment, timedependent attachment irreversibility, and other mechanisms of interest.

Hydrogeophysical Characterization: The South Oyster Site was a critical venue for the application and testing of a suite of new hydrogeophysical applications and methods for analysis, interpretation, and integration with numerical models. A comparison of model predictions with extensive field breakthrough observations provided the basis for evaluation of the worth of various types of field data in conditioning a tracer transport model, and clearly demonstrated the efficacy of non-invasive hydrogeophysical measurements for improving 
predictions, even when compared with more extensive borehole-based hydrologic characterization than is available at typical field sites.

Integrated Field Research: The success of the South Oyster Site research effort led to continued investment by the Department of Energy in field research focused on highly characterized field sites. Today, several former South Oyster Site investigators are involved in ongoing research at DOE-sponsored field research sites known as Integrated Field Research Challenge (IFRC) sites. These sites are located in Rifle CO (e.g.,Williams et al. 2009; Fang et al. 2009; Chen et al. 2009), Oak Ridge TN (e.g., Wu et al. 2006a, 2006b) and Hanford WA (e.g., Gee et al. 2007; McKinley et al. 2007). Although these sites focus on aspects of subsurface biogeochemistry other than bacterial transport, the value placed by DOE programs on multidisciplinary, multi-institution, collaborative field research is in part a legacy of the success of research at the South Oyster Site. As was done at the South Oyster Site, these current projects incorporate multi-disciplinary teams of scientists with strong focus on advanced field-scale characterization methods, combination of laboratory and field studies to identify key processes, and integration of diverse data types within a numerical modeling framework.

We have provided a brief summary of selected aspects of research conducted at the South Oyster bacterial transport site. Since this effort involved a large number of researchers with diverse backgrounds and interests, a large number of papers were published that addressed research hypotheses related to the primary aspects discussed here. Therefore, we conclude this paper with Table 2, which contains a listing of known papers based in whole or in part on South Oyster site research and a very brief summary of the key conclusions of each. The reader is encouraged to browse this table and read papers of interest to gain further information 
regarding the South Oyster site project and its diverse contributions to a number of scientific disciplines. The number of known citations to each paper is provided in the table; a statistical summary of publication statistics is given in Figure 5. The significant impact of research conducted at the Oyster Site is indicated by these 60 papers, cited a total of 1478 times to date (an average of 25 citations per paper), and having an equivalent " $\mathrm{H}$-index" of 23 . The most cited paper in the group (83 citations) is an invited review of microbial transport processes (Ginn et al. 2002).

Table 2. List of known publications related to the South Oyster site bacterial transport research. Numbers in parentheses following the citations are the current (January 2011) number of citations to each work as listed in ISI Web of Science (except where noted* from Google Scholar).

\begin{tabular}{|l|l|}
\hline \multicolumn{1}{|c|}{ Citation } & \multicolumn{1}{c|}{ Key Conclusions and/or Contributions } \\
\hline $\begin{array}{c}\text { Balkwill et al. 2001 } \\
\text { (NA) }\end{array}$ & $\begin{array}{l}\text { A high-level summary of South Oyster Site research aimed at increasing } \\
\text { awareness of the project within the scientific community. Published in EOS, } \\
\text { the weekly newspaper of the American Geophysical Union. }\end{array}$ \\
\hline $\begin{array}{c}\text { Basagaoglu et al. 2002 } \\
(0)\end{array}$ & $\begin{array}{l}\text { Presents and evaluates the formulation of tracer transport in heterogeneous } \\
\text { media by temporal moments based on networks of parallel and series unit } \\
\text { models representing batch systems, homogeneous columns, or mass-transfer- } \\
\text { connected compartments. }\end{array}$ \\
\hline $\begin{array}{l}\text { Brockman and Murray, } \\
\text { 1997a (37) }\end{array}$ & $\begin{array}{l}\text { Review of studies and current understanding of microbiological } \\
\text { heterogeneity in the subsurface. Includes data and analysis from early } \\
\text { studies performed in excavations near the Oyster Site that guided subsequent } \\
\text { studies (see Zhang et al. 1997; 1998). }\end{array}$ \\
\hline $\begin{array}{l}\text { Brockman and Murray, } \\
\text { 1997b (NA) }\end{array}$ & $\begin{array}{l}\text { Chapter in edited volume on microbiology of the terrestrial subsurface. } \\
\text { Review article discusses the importance of microbiological heterogeneity, } \\
\text { associated scales of heterogeneity, and geostatistical methods for quantifying } \\
\text { heterogeneity }\end{array}$ \\
\hline $\begin{array}{l}\text { Burger and Belitz 1997 } \\
\text { (23) }\end{array}$ & $\begin{array}{l}\text { Describes a method for collecting and analyzing undisturbed cores parallel } \\
\text { and perpendicular to primary bedding structures. 64 samples from four } \\
\text { different lithofacies identified at an outcrop near the Oyster Site were } \\
\text { analyzed and showed permeability anisotropy of 1.33 to 1.57 (parallel- }\end{array}$ \\
\hline
\end{tabular}




\begin{tabular}{|c|c|}
\hline & oriented higher). \\
\hline Chen et al. 2001 (42) & $\begin{array}{l}\text { Describes a stochasatic methodology for inferring hydraulic conductivity } \\
\text { from cross-borehole geophysical observations as applied at the Oyster Site }\end{array}$ \\
\hline Chen et al. 2004 (15) & $\begin{array}{l}\text { Geostatistical characterization of geochemical properties (iron oxide } \\
\text { concentration) based on geophysical data }\end{array}$ \\
\hline $\begin{array}{l}\text { Cushman and Ginn } \\
2000(42)\end{array}$ & $\begin{array}{l}\text { Demonstrates equivalence between an advection-dispersion model with } \\
\text { fractional (non-integer) derivatives (fractional ADE’s or FADE models) and } \\
\text { the more general convolution-Fickian non-local advection-dispersion } \\
\text { equation. }\end{array}$ \\
\hline $\begin{array}{l}\text { DeFlaun et al. } 1997 \\
\text { (57) }\end{array}$ & $\begin{array}{l}\text { Describes preliminary microbial transport experiments conducted at a nearby } \\
\text { location prior to development of the South Oyster Site }\end{array}$ \\
\hline $\begin{array}{l}\text { DeFlaun et al. } 1999 \\
\text { (51) }\end{array}$ & $\begin{array}{l}\text { Demonstrated successful development of an adhesion-deficient bacterium by } \\
\text { repeated culturing to subselect for a sub-population of an Oyster Site native } \\
\text { strain }\end{array}$ \\
\hline $\begin{array}{l}\text { DeFlaun et al. } 2001 \\
\text { (12) }\end{array}$ & $\begin{array}{l}\text { Compares results from several techniques used to measure bacterial } \\
\text { concentrations in groundwater at the Oyster Site }\end{array}$ \\
\hline Dong et al. 1999 (6) & $\begin{array}{l}\text { Describes detailed characterization methods used for post-experimental } \\
\text { characterization of bacterial transport in sediment cores. See also Dong et al. } \\
\text { 2002a. }\end{array}$ \\
\hline Dong et al. 2002a (36) & $\begin{array}{l}\text { Detailed analysis of intact sediment columns to evaluate the relative impact } \\
\text { of physical and chemical heterogeneity on microbial transport }\end{array}$ \\
\hline Dong et al. 2002b (49) & $\begin{array}{l}\text { Theoretical development of an approach to predict collision efficiency } \\
\text { (alpha) based on sediment and bacterial cell surface properties }\end{array}$ \\
\hline Dong et al. 2002c (20) & $\begin{array}{l}\text { Comparative study of transport of two different bacteria (DA001 and } \\
\text { OYS2A) by simultaneous injection into the same columns. Demonstrates } \\
\text { significant differences in transport behavior that are controlled by microbial } \\
\text { cell properties (all other factors being the same). }\end{array}$ \\
\hline Dong 2002 (21) & $\begin{array}{l}\text { Describes development and application of a method to measure the } \\
\text { distribution of electrophoretic mobility of a population of particles } \\
\text { (microbes). For strain DA001, it is shown that the predicted collision } \\
\text { efficiency values associated with the measured distribution varies over } \\
\text { orders of magnitude, indicating that microbial cell surface charge } \\
\text { heterogeneity is significant in terms of experimental distributions of alpha. } \\
\text { Also demonstrates the inability of DLVO theory alone to explain the } \\
\text { observed variability in alpha and suggests other contributing factors. }\end{array}$ \\
\hline Dong et al. 2006 (3) & $\begin{array}{l}\text { Describes and analyzes results of column experiments conducted in the field } \\
\text { using bacterial suspensions collected from wells at varying distance from th } \\
\text { injection well. See also Scheibe et al. } 2007 \text {. }\end{array}$ \\
\hline $\begin{array}{l}\text { Finneran et al. } 2003 \\
\text { (71) }\end{array}$ & $\begin{array}{l}\text { Describes a novel strain of Rhodoferax bacteria that is capable of } \\
\text { dissimilatory iron reduction, isolated from Oyster Site sediments }\end{array}$ \\
\hline Fuller et al. 2000a (24) & $\begin{array}{l}\text { Presents results of bacterial transport column experiments conducted using } \\
\text { intact cores collected from a nearby excavation. Included analysis of } \\
\text { attached concentration as a function of distance along the cores (by } \\
\text { destructive post-experimental sampling). Cores were collected to be } \\
\text { representative of identified geologic facies; bacterial transport was most } \\
\text { influenced by mean grain size and total metal hydroxide content. }\end{array}$ \\
\hline Fuller et al. 2000b (47) & $\begin{array}{l}\text { Describes a new vital fluorescent staining method used to distinguish } \\
\text { injected bacteria from native bacteria of the same strain. See also DeFlaun et } \\
\text { al. } 2001 \text {. }\end{array}$ \\
\hline
\end{tabular}




\begin{tabular}{|c|c|}
\hline Fuller et al. 2001 (15) & $\begin{array}{l}\text { Evaluates staining of microbial cells with a fluorescent compound combined } \\
\text { with multiple cell detection methods as a means of monitoring bacterial } \\
\text { transport during field experiments. }\end{array}$ \\
\hline Ginn 2000a (7) & $\begin{array}{l}\text { Theoretical development of exposure-time formulation of equations } \\
\text { governing residence-time distributions of material in particular states with } \\
\text { mass transfer between states. Illustrated by two-site attachment/detachment } \\
\text { problem. }\end{array}$ \\
\hline Ginn 2000b (7) & $\begin{array}{l}\text { Comment on published work by others discusses the implications of that } \\
\text { work in terms of the process of size exclusion. }\end{array}$ \\
\hline Ginn 2001 (26) & $\begin{array}{l}\text { Development of a streamtube ensemble method to upscale transport with } \\
\text { multicomponent nonlinear reactions in steady nonuniform flow. }\end{array}$ \\
\hline Ginn et al. 2002 (83) & $\begin{array}{l}\text { Invited review of microbial transport processes and modeling. Includes a } \\
\text { description of Oyster Site research as a case study. }\end{array}$ \\
\hline Ginn 2002 (13) & $\begin{array}{l}\text { Theoretical development of a model of exclusion based on travel time } \\
\text { distributions. }\end{array}$ \\
\hline Hall et al. 2005 (11) & $\begin{array}{l}\text { Analysis of relative importance of physical vs. chemical properties of aquifer } \\
\text { material on bacterial transport. Based on multiple sediment column } \\
\text { experiments conducted on-site using Oyster Site groundwater. }\end{array}$ \\
\hline $\begin{array}{l}\text { Holben and Ostrom, } \\
2000(12)\end{array}$ & $\begin{array}{l}\text { Describes method for tracking bacteria based on stable isotope enrichment. } \\
\text { See also DeFlaun et al. } 2001 .\end{array}$ \\
\hline $\begin{array}{l}\text { Hubbard et al. 1997a } \\
\left(71^{*}\right)\end{array}$ & $\begin{array}{l}\text { Use of Oyster crosshole radar data to estimate water content along 2D } \\
\text { transect followed by validation using neutron probe data. Awarded one of } \\
\text { the 'Most Influential Articles' published by Leading Edge of Exploration in } \\
2008 \text {. }\end{array}$ \\
\hline $\begin{array}{l}\text { Hubbard et al. 1997b } \\
\text { (52) }\end{array}$ & $\begin{array}{l}\text { Presents a stochastic technique for estimation of water content and } \\
\text { permeability in the vadose zone, using combination of ground-penetrating } \\
\text { radar measurements and petrophysical relationships. The approach is tested } \\
\text { using some numerical case studies. }\end{array}$ \\
\hline $\begin{array}{l}\text { Hubbard et al. } 1999 \\
\text { (38) }\end{array}$ & $\begin{array}{l}\text { Analysis of spatial correlation structure of Oyster Site aquifer properties } \\
\text { (hydraulic conductivity) based on hydrogeophysical analysis }\end{array}$ \\
\hline $\begin{array}{l}\text { Hubbard et al. } 2000 \\
\text { (34) }\end{array}$ & $\begin{array}{l}\text { Review of hydrogeophysical parameter estimation methods with examples } \\
\text { from the Oyster Site }\end{array}$ \\
\hline $\begin{array}{l}\text { Hubbard et al., } 2001 \\
\text { (75) }\end{array}$ & $\begin{array}{l}\text { Multi-scale characterization of Oyster subsurface geometry and hydraulic } \\
\text { properties using geophysical data and comparison of obtained estimates with } \\
\text { tracer test data. }\end{array}$ \\
\hline $\begin{array}{l}\text { Hubbard and Linde, in } \\
\text { press. }\end{array}$ & $\begin{array}{l}\text { Describes key components and choices associated with hydrogeophysical } \\
\text { methodologies and presents several field-scale case studies, including one } \\
\text { based on Oyster }\end{array}$ \\
\hline $\begin{array}{l}\text { Johnson et al. } 2001 \\
(27)\end{array}$ & $\begin{array}{l}\text { Describes application of ferromagnetic separation to microbial tracking at } \\
\text { the Oyster Site. See also Zhang et al. } 1999 \text { and DeFlaun et al. } 2001 .\end{array}$ \\
\hline $\begin{array}{l}\text { Johnson et al. 2001b } \\
\text { (10) }\end{array}$ & $\begin{array}{l}\text { Uses combined results of two bacterial monitoring methods (vital fluorescent } \\
\text { staining and ferrographic capture) to distinguish injected and indigenous } \\
\text { bacteria of the same strain in groundwater samples. Arrival of injected } \\
\text { bacteria at sampling points was accompanied by a large increase in non- } \\
\text { stained (indigenous) bacteria. Their potential origin and mechanism are } \\
\text { discussed. }\end{array}$ \\
\hline $\begin{array}{l}\text { Johnson and McIntosh } \\
2003 \text { (2) }\end{array}$ & $\begin{array}{l}\text { Further examines the question of whether injected cells cause enhanced } \\
\text { detachment of previously attached bacteria. (see also Johnson et al., 2001b) }\end{array}$ \\
\hline Li et al., $2004(75)$ & Study of scale dependence of attachment rates and relationship to \\
\hline
\end{tabular}




\begin{tabular}{|c|c|}
\hline & $\begin{array}{l}\text { unfavorable attachment conditions. Uses numerical model and concepts } \\
\text { developed under the Oyster project. }\end{array}$ \\
\hline Linde et al. 2006a (3) & $\begin{array}{l}\text { Discussion of benefits and limitations of various hydrogeophysical } \\
\text { estimation approaches, with examples of different approaches to Oyster } \\
\text { datasets. }\end{array}$ \\
\hline Linde et al. 2006b (17) & $\begin{array}{l}\text { Presents a new method for estimating hydraulic conductivity fields by } \\
\text { inversion of tracer test data combined with zonation developed from cross- } \\
\text { borehole ground-penetrating radar measurements. The method also provides } \\
\text { information on the petrophysical relationship between radar velocity and } \\
\text { hydraulic conductivity. Applies and tests the methodology numerically using } \\
\text { a synthetic hydraulic conductivity field. }\end{array}$ \\
\hline Linde et al. 2008 (7) & $\begin{array}{l}\text { Presents a study of simultaneous (joint) inversion of cross-borehole radar } \\
\text { and seismic observations. Application to a synthetic dataset demonstrates } \\
\text { that joint inversion provides better estimates of lithologic boundaries than } \\
\text { individual inversions alone. The inversion scheme is also applied to data } \\
\text { from the Oyster Site and provide improved correlation of estimated hydraulic } \\
\text { conductivity values with those measured using borehole flowmeter methods. }\end{array}$ \\
\hline Lytle et al. 2001 (5) & $\begin{array}{l}\text { Describes a novel method of bacterial tracking based on lipid analysis of C- } \\
13 \text { labeled bacteria. See also DeFlaun et al. } 2001 .\end{array}$ \\
\hline $\begin{array}{l}\text { Mailloux et al. 2003a } \\
\text { (14) }\end{array}$ & $\begin{array}{l}\text { Based on Narrow Channel injection experiment. Analyzes relative } \\
\text { importance of various types of heterogeneity and proposes method for } \\
\text { transferring column observations to field-scale models based on observed } \\
\text { distributions of collision efficiency parameter. }\end{array}$ \\
\hline $\begin{array}{l}\text { Mailloux et al. 2003b } \\
\text { (2) }\end{array}$ & $\begin{array}{l}\text { Describes field methods and equipment developed for the bacterial transport } \\
\text { experiments at the Oyster Site }\end{array}$ \\
\hline $\begin{array}{l}\text { Mailloux and Fuller } \\
2003(10)\end{array}$ & $\begin{array}{l}\text { Presents method and results of determining micriobial growth rates in the } \\
\text { aquifer based on analysis of intensity of vital fluorescent stain (see Fuller et } \\
\text { al. 2000b) }\end{array}$ \\
\hline $\begin{array}{l}\text { Murphy and Ginn, } \\
2000 \text { (68) }\end{array}$ & $\begin{array}{l}\text { Review paper discussing state of the art and issues in modeling microbial } \\
\text { processes in porous media. }\end{array}$ \\
\hline $\begin{array}{l}\text { Musselwhite et al } 2003 \\
\text { (12) }\end{array}$ & $\begin{array}{l}\text { Examines the spatial variability of and interrelationships among } \\
\text { microbiological, sedimentological, and geochemical properties of vadose } \\
\text { zone sediments at an excavation near the Oyster site. }\end{array}$ \\
\hline $\begin{array}{l}\text { Musselwhite et al } 2007 \\
\text { (4) }\end{array}$ & $\begin{array}{l}\text { Examines the distribution and metabolic activity of sulfate-reducing bacteria } \\
\text { in Oyster sediments using a radioimaging technique (cm-scale resolution). } \\
\text { Sediment porosity and pore size were observed to be the primary } \\
\text { sedimentological factor related to sulfate-reducing activity. }\end{array}$ \\
\hline $\begin{array}{l}\text { Nelson and Ginn, } 2001 \\
\text { (13) }\end{array}$ & $\begin{array}{l}\text { Particle tracking analysis of the potential effect of chemotaxis (microbial } \\
\text { swimming in response to a chemical gradient) on attachment in the CFT } \\
\text { framework }\end{array}$ \\
\hline Parsons et al. 2004 (2) & $\begin{array}{l}\text { Sedimentological characterization of facies stratigraphy in near-surface } \\
\text { sediments of the Oyster Site area. }\end{array}$ \\
\hline $\begin{array}{l}\text { Scheibe et al. } 2001 \\
(21)\end{array}$ & $\begin{array}{l}\text { Describes the premodeling process used to support design of the microbial } \\
\text { transport experiments at the Oyster Site }\end{array}$ \\
\hline $\begin{array}{l}\text { Scheibe and Chien, } \\
2003 \text { (16) }\end{array}$ & $\begin{array}{l}\text { A numerical study of the impact of different types and amounts of data } \\
\text { (hydrological, geophysical) on predictions of solute transport with } \\
\text { comparisons to Oyster Site observations. Clearly demonstrates the value of } \\
\text { hydrogeophysical data in conditioning geostatistical aquifer models. }\end{array}$ \\
\hline Scheibe and Wood, & Describes a particle tracking model that incorporates microbial exclusion \\
\hline
\end{tabular}




\begin{tabular}{|c|c|}
\hline $2003(20)$ & through truncation of the distribution of dispersive displacements. \\
\hline Scheibe et al. 2006 (9) & $\begin{array}{l}\text { A numerical experiment evaluating the impact of joint physical and chemical } \\
\text { heterogeneity in a hypothetical uranium bioremediation problem. Uses } \\
\text { extensive data from the Oyster Site to support the model property } \\
\text { distributions used. }\end{array}$ \\
\hline $\begin{array}{l}\text { Scheibe et al. } 2007 \\
\text { (10) }\end{array}$ & $\begin{array}{l}\text { Provides numerical support for the hypothesis that apparent scale } \\
\text { dependence of collision efficiency is caused by inverse correlation between } \\
\text { hydraulic conductivity and bacterial attachment rate. }\end{array}$ \\
\hline $\begin{array}{l}\text { Seeboonruang and } \\
\text { Ginn 2006a (7) }\end{array}$ & $\begin{array}{l}\text { Theoretical development and testing of a modeling approach based on } \\
\text { accounting of solute flux exposure to reactive surfaces over time. Combines } \\
\text { non-reactive tracer simulations with stochastic realizations of reactive site } \\
\text { density fields to determine characteristic nature of multiscale reactive } \\
\text { heterogeneity. This paper focuses on forward simulation approach; the } \\
\text { companion paper (Seeboonruang and Ginn 2006b) describes an inverse } \\
\text { model application. }\end{array}$ \\
\hline $\begin{array}{l}\text { Seeboonruang and } \\
\text { Ginn 2006b (1) }\end{array}$ & $\begin{array}{l}\text { Presents a novel inverse method for characterizing heterogeneous aquifer } \\
\text { reactivity using a Lagrangian framework. Represents reactive heterogeneity } \\
\text { in terms of flux distributions over cumulative exposure time of a solute to } \\
\text { reactive surface area (see companion paper Seeboonruang and Ginn 2006a) }\end{array}$ \\
\hline Tobin et al. 1999 (12) & $\begin{array}{l}\text { Presents a protocol that enables visualization of intact microorganisms in } \\
\text { petrographic thin sections without disruption of the rock texture or the } \\
\text { detachment of microorganisms from host mineral surfaces. }\end{array}$ \\
\hline $\begin{array}{l}\text { Wildung et al. } 2004 \\
\text { (31) }\end{array}$ & $\begin{array}{l}\text { Examimes the rate of reduction of technetium (pertechnetate ion) in sediment } \\
\text { samples from the suboxic region of the Oyster site. The dominant electron } \\
\text { donor was observed to be reduced iron (Fe(II)), and the rate and observed } \\
\text { extent of reduction varied dramatically between sediment samples. Results } \\
\text { suggest that stimulation of enhanced microbial reduction of Fe(III) could led } \\
\text { to reductive immobilization of technetium. }\end{array}$ \\
\hline Zhang et al. 1997 (8) & $\begin{array}{l}\text { Presents results of studies characterizing variations in microbial abundance, } \\
\text { activity, and community profiles at centimeter and meter scales at an } \\
\text { exposure near the Oyster Site. Results indicate that sediment water content } \\
\text { and nutrient availability (associated with land use) can have a dominant } \\
\text { effect on the spatial distribution of microbial properties in the shallow } \\
\text { subsurface. }\end{array}$ \\
\hline Zhang et al. 1998 (16) & $\begin{array}{l}\text { Describes study of spatial variability of microbial population density at an } \\
\text { excavation near the Oyster Site }\end{array}$ \\
\hline Zhang et al. 1999 (13) & $\begin{array}{l}\text { Describes a novel and highly sensitive method for tracking injected bacteria } \\
\text { based on attachment of a ferromagnetic bead to each cell allowing magnetic } \\
\text { separation following sample collection (see also Johnson et al. 2001) }\end{array}$ \\
\hline Zhang et al. 2001 (43) & $\begin{array}{l}\text { Describes and analyzes late time breakthrough of low concentrations of } \\
\text { bacteria following the end of an injection experiment at the Oyster Site. } \\
\text { Also presents data on protozoan population effects and potential impacts on } \\
\text { bacterial transport. }\end{array}$ \\
\hline
\end{tabular}




\section{References Cited}

Atekwana, A. and L. Slater. 2009. Biogeophysics: A New Frontier in Earth Science Research. Reviews of Geophysics 47: RG4004, doi:10.1029/2009RG000285.

Balkwill, D., M. DeFlaun, F. Dobbs, J. Fredrickson, M. Fuller, M. Green, T. Ginn, T. Griffin, W. Holben, S. Hubbard, W. Johnson, P. Long, E. Majer, M. Mclnerney, T. Onstott, T. Phelps, T. Scheibe, D. Swift, D. White, and F. Wobber. 2001. Breakthroughs in Field-Scale Bacterial Transport. EOS Transactions AGU 82, no. 38: 417,423-425.

Basagaoglu, H., T. R. Ginn, C. T. Green, and B. J. McCoy. 2002. Transport in Heterogeneous Media: Tracer Dynamics in Complex Flow Networks. AIChE Journal 48, no. 5: 1121-1131, 2002.

Bolster, C. H., A. L. Mills, G. Hornberger, and J. Herman. 2000. Effect of intrapopulation variability on the long-distance transport of bacteria. Ground Water 38, no. 3: 370-375.

Bradford, S. A., J. Simunek, M. Bettahar, M. T. van Genuchten, and S. R. Yates. 2006. Significance of straining in colloid deposition: Evidence and implications. Water Resources Research 42, no. 12: W12S15.

Brockman, F. J. and C. J. Murray. 1997a. Subsurface microbiological heterogeneity: Current knowledge, descriptive approaches, and applications. FEMS Microbiology Reviews 20, no. 34: 231-247.

Brockman, F. J. and C. J. Murray. 1997b. Microbiological heterogeneity. In Microbiology of the Terrestrial Subsurface, ed. P. Amy and D. Haldeman, 75-102. Boca Raton, Florida: CRC Press. 
Burger, R. L. and K. Belitz. 1997. Measurement of anisotropic hydraulic conductivity in unconsolidated sands: A case study from a shoreface deposit, Oyster, Virginia. Water Resources Research 33, no. 6: 1515-1522.

Chen, J. S., S. Hubbard, and Y. Rubin. 2001. Estimating the hydraulic conductivity at the South Oyster Site from geophysical tomographic data using Bayesian techniques based on the normal linear regression model. Water Resources Research 37, no. 6: 1603-1613.

Chen, J. and Y. Rubin. 2003. An effective Bayesian model for lithofacies estimation using geophysical data. Water Resources Research 39, no. 5: 1118.

Chen, J. S., S. Hubbard, Y. Rubin, C. Murray, E. Roden, and E. Majer. 2004. Geochemical characterization using geophysical data and Markov chain Monte Carlo methods: A case study at the South Oyster bacterial transport site in Virginia. Water Resources Research 40, no. 12: W12412.

Chen, J. S., S. S. Hubbard, K. H. Williams, S. Pride, L. Li, C. Steefel, and L. Slater. 2009. A statespace Bayesian framework for estimating biogeochemical transformations using time-lapse geophysical data. Water Resources Research 45: W08420.

Cushman, J. H. and T. R. Ginn. 2000. Fractional advection-dispersion equation: A classical mass balance with convolution-Fickian flux. Water Resources Research 36, no. 12: 3763-3766.

DeFlaun, M. F., C. J. Murray, W. Holben, T. Scheibe, A. Mills, T. Ginn, T. Griffin, E. Majer, and J. L. Wilson. 1997. Preliminary observations on bacterial transport in a coastal plain aquifer. FEMS Microbiology Reviews 20, no. 3-4: 473-487. 
DeFlaun, M. F., S. R. Oppenheimer, S. Streger, C. W. Condee, and M. Fletcher. 1999. Alterations in adhesion, transport, and membrane characteristics in an adhesion-deficient pseudomonad. Applied and Environmental Microbiology 65, no. 2: 759-765.

DeFlaun, M. F., M. E. Fuller, P. F. Zhang, W. P. Johnson, B. J. Mailloux, W. E. Holben, W. P. Kovacik, D. L. Balkwill, and T. C. Onstott. 2001. Comparison of methods for monitoring bacterial transport in the subsurface. Journal of Microbiological Methods 47, no. 2: 219-231.

Dong, H. L., T. C. Onstott, M. F. Deflaun, M. E. Fuller, K. M. Gillespie, and J. K. Fredrickson. 1999. Development of radiographic and microscopic techniques for the characterization of bacterial transport in intact sediment cores from Oyster, Virginia. Journal of Microbiological Methods 37, no. 2: 139-154.

Dong, H. L., T. C. Onstott, M. F. DeFlaun, M. E. Fuller, T. D. Scheibe, S. H. Streger, R. K. Rothmel, and B. J. Mailloux. 2002a. Relative dominance of physical versus chemical effects on the transport of adhesion-deficient bacteria in intact cores from South Oyster, Virginia. Environmental Science \& Technology 36, no. 5: 891-900.

Dong, H. L., T. C. Onstott, C. H. Ko, A. D. Hollingsworth, D. G. Brown, and B. J. Mailloux. 2002b. Theoretical prediction of collision efficiency between adhesion-deficient bacteria and sediment grain surfaces. Colloids and Surfaces B - Biointerfaces 24, no. 3-4: 229-245.

Dong, H., R. Rothmel, T. C. Onstott, M. E. Fuller, M. F. Deflaun, S. H. Streger, R. Dunlap, and M. Fletcher. 2002c. Simultaneous transport of two bacterial strains in intact cores from Oyster, Virginia: Biological effects and numerical modeling. Applied and Environmental Microbiology 68, no. 5: $2120-2132$. 
Dong, H. 2002. "Significance of electrophoretic mobility distribution to bacterial transport in granular porous media. Journal of Microbiological Methods 51, no. 1: 83-93.

Dong, H. L., T. D. Scheibe, W. P. Johnson, C. M. Monkman, and M. E. Fuller. 2006. Change of collision efficiency with distance in bacterial transport experiments. Ground Water 44, no. 3: 415-429.

Fang, Y., S. Yabusaki, S. Morrison, J. P. Amonette, and P. Long. 2009. Multicomponent reactive transport modeling of uranium bioremediation field experiments. Geochimica et Cosmochimica Acta 73, no. 20: 6029-6051.

Finneran K. T., C. V. Johnsen, and D. R. Lovley. 2003. Rhodoferax ferrireducens sp. nov., a psychrotolerant, facultatively anaerobic bacterium that oxidizes acetate with the reduction of Fe(III). International Journal of Systematic and Evolutionary Microbiology 53, no. 3: 669673.

Fuller, M. E., H. L. Dong, B. J. Mailloux, T. C. Onstott, and M. F. DeFlaun. 2000a. Examining bacterial transport in intact cores from Oyster, Virginia: Effect of sedimentary facies type on bacterial breakthrough and retention. Water Resources Research 36, no. 9: 2417-2431.

Fuller, M. E., S. H. Streger, R. K. Rothmel, B. J. Mailloux, J. A. Hall, T. C. Onstott, J. K. Fredrickson, D. L. Balkwill, and M. F. DeFlaun. 2000b. Development of a vital fluorescent staining method for monitoring bacterial transport in subsurface environments. Applied and Environmental Microbiology 66, no. 10: 4486-4496.

Fuller M. E., B. J. Mailloux, P. Zhang, S. H. Streger, J. A. Hall, S. N. Vainberg, A. J. Beavis, W. P. Johnson, T. C. Onstott, and M. F. DeFlaun. Field-scale evaluation of CFDA/SE staining 
coupled with multiple detection methods for assessing the transport of bacteria in situ. FEMS Microbiol Ecology 37, no. 1: 55-66.

Gao, H., C. Q. Qiu, D. M. Fan, Y. Jin and L. P. Wang. 2010. Three-dimensional microscale flow simulation and colloid transport modeling in saturated soil porous media. Computers \& Mathematics with Applications 59, no. 7: 2271-2289.

Gee, G. W., M. Oostrom, M. D. Freshley, M. L. Rockhold, and J. M. Zachara. 2007. Hanford Site vadose zone studies: An overview. Vadose Zone Journal 6, no. 4: 985-1003.

Ginn, T. R. 2000a. On the distribution of multicomponent mixtures over generalized exposure time in subsurface flow and reactive transport: Batch and column applications involving residence-time distributions and non-Markovian reaction kinetics. Water Resources Research 36, no. 10: 2895-2903.

Ginn, T. R. 2000b. Comment on 'Stochastic analysis of virus transport in aquifers,' by Linda L. Campbell Rehmann, Claire Welty, and Ronald W. Harvey. Water Resources Research 36, no. 7: 1981-1982.

Ginn, T. R. 2001. Stochastic-convective transport with nonlinear reactions and mixing: Finite streamtube ensemble formulation for multicomponent reaction systems with intrastreamtube dispersion. Journal of Contaminant Hydrology 47, no. 1: 1-28.

Ginn, T. R., B. D. Wood, K. E. Nelson, T. D. Scheibe, E. M. Murphy, and T. P. Clement. 2002. Processes in microbial transport in the natural subsurface. Advances in Water Resources 25, no. 8-12: 1017-1042.

Ginn, T. R. 2002. A travel time approach to exclusion on transport in porous media. Water Resources Research 38, no. 4: 1041. 
Hall, J. A., B. J. Mailloux, T. C. Onstott, T. D. Scheibe, M. E. Fuller, H. Dong, and M. F. DeFlaun. 2005. Physical versus chemical effects on bacterial and bromide transport as determined from on site sediment column pulse experiments. Journal of Contaminant Hydrology, 76, no. 3-4: 295-314.

Harvey R. W. and S. P. Garabedian. 1991. Use of colloid filtration theory in modeling movement of bacteria through a contaminated sandy aquifer. Environmental Science \& Technology 25, no. 1: 178-185.

Holben, W. E. and P. H. Ostrom. 2000. Monitoring bacterial transport by stable isotope enrichment of cells. Applied and Environmental Microbiology 66, no. 11: 4935-4939.

Hubbard, S., Peterson, J.E., Majer, E.L., Zawislanski, P.T., Roberts, J., Williams, K.H. and Wobber, F. 1997a. Estimation of permeable pathways and water content using tomographic radar data. The Leading Edge of Exploration 16, no. 11: 1623-1628.

Hubbard S. S., Y. Rubin, and E. Majer. 1997b. Ground-penetrating-radar-assisted saturation and permeability estimation in bimodal systems. Water Resources Research 33, no. 5: 971-990. Hubbard, S. S., Y. Rubin, and E. Majer. 1999. Spatial correlation structure estimation using geophysical and hydrogeological data. Water Resources Research 35, no. 6: 1809-1825.

Hubbard, S. S. and Y. Rubin. 2000. Hydrogeological parameter estimation using geophysical data: a review of selected techniques. Journal of Contaminant Hydrology 45, no. 1-2: 3-34. Hubbard, S. S., J. Chen, J. Peterson, E. L. Majer, K. H. Williams, D. J. Swift, B. Mailloux, and Y. Rubin. 2001. Hydrogeological characterization of the South Oyster bacterial transport site using geophysical data. Water Resources Research 37, no. 10: 2431-2456. 
Hubbard, S. S., K. Williams, M. E. Conrad, B. Faybishenko, J. Peterson, J. Chen, P. Long, and T. Hazen. 2008. Geophysical monitoring of hydrological and biogeochemical transformations associated with $\mathrm{Cr}(\mathrm{VI})$ bioremediation. Environmental Science and Technology 42, no. 10: 3757-3765.

Hubbard, S._and N. Linde. 2011. Hydrogeophysics. In Hydrology, Treatise in Water Science, vol. 2, ed. S. Uhlenbrook. Elsevier, (in press).

Johnson, P. R., N. Sun, and M. Elimelech. 1996. Colloid transport in geochemically heterogeneous porous media: Modeling and measurements. Environmental Science \& Technology 30, no. 11: 3284-3293.

Johnson, W. P., K. A. Blue, B. E. Logan, and R. G. Arnold. 1995. Modeling bacterial detachment during transport through porous media as a residence-time-dependent process. Water Resources Research 31, no. 11: 2649-2658.

Johnson, W. P. , P. Zhang, M. E. Fuller, T. D. Scheibe, B. J. Mailloux, T. C. Onstott, M. F. DeFlaun, S. S. Hubbard, J. Radtke, W. P. Kovacik, and W. Holben. 2001a. Ferrographic tracking of bacterial transport in the field at the Narrow Channel focus area, Oyster, VA. Environmental Science \& Technology 35, no. 1: 182-191.

Johnson W. P., P. Zhang, P. M. Gardner, M. E. Fuller, and M. F. DeFlaun. 2001b. Evidence for detachment of indigenous bacteria from aquifer sediment in response to arrival of injected bacteria. Applied and Environmental Microbiology 67, no. 10: 4908-4913.

Johnson W. P. and W. O. McIntosh. 2003. Tracking of injected and resident (previously injected) bacterial cells in groundwater using ferrographic capture. Journal of Microbiological Methods 54, no. 2: 153-164. 
Johnson, W. P., X. Q. Li and G. Yal. 2007. Colloid retention in porous media: Mechanistic confirmation of wedging and retention in zones of flow stagnation. Environmental Science \& Technology 41, no. 4: 1279-1287.

Knapp, E. P., J. S. Herman, G. M. Hornberger, and A. L. Mills. 1998. The effect of distribution of iron-oxyhydroxide grain coatings on the transport of bacterial cells in porous media. Environmental Science \& Technology 33, no. 4: 243-248.

Li, Z., D. Zhang and X. Li. 2010a. Tracking colloid transport in porous media using discrete flow fields and sensitivity of simulated colloid deposition to space discretization. Environmental Science \& Technology 44, no. 4: 1274-1280.

Li, X., T. D. Scheibe and W. P. Johnson. 2004. Apparent decreases in colloid deposition rate coefficients with distance of transport under unfavorable deposition conditions: A general phenomenon. Environmental Science \& Technology 38, no. 21: 5616-5625.

Li, X. Q., C. L. Lin, J. D. Miller and W. P. Johnson. 2006. Pore-scale observation of microsphere deposition at grain-to-grain contacts over assemblage-scale porous media domains using Xray microtomography. Environmental Science \& Technology 40, no. 12: 3762-3768.

Li, X. Q., Z. L. Li and D. X. Zhang. 2010b. Role of low flow and backward flow zones on colloid transport in pore structures derived from real porous media. Environmental Science \& Technology 44, no. 13: 4936-4942.

Linde, N., J. Chen, M. B. Kowalsky and S. Hubbard. 2006a. Hydrogeophysical parameter estimation approaches for field scale characterization. In Applied Hydrogeophysics, ed. H. Vereecken, A. Binley, G. Cassiani, A. Revil, and K. Titov, 9-44. Dordrecht: Springer. 
Linde, N., S. Finsterle, and S. Hubbard. 2006b. Inversion of tracer test data using tomographic constraints. Water Resources Research 42, no. 4: W04410.

Linde, N., A. Tryggvason, J.E. Peterson and S.S. Hubbard. 2008. Joint inversion of crosshole radar and seismic traveltimes acquired at the South Oyster Bacterial Transport Site. Geophysics 73, no. 4: G29-G37.

Logan, B. E., D. G. Jewett, R. G. Arnold, E. J. Bouwer, and C. R. O'Melia. 1995. Clarification of clean-bed filtration models. Journal of Environmental Engineering 121, no. 12: 869-873.

Lytle, C. A., M. E. Fuller, Y. D. M. Gan, A. Peacock, M. F. DeFlaun, T. C. Onstott, and D. C. White. 2001. Utility of high performance liquid chromatography/electrospray/mass spectrometry of polar lipids in specifically Per-C-13 labeled Gram-negative bacteria DA001 as a tracer for acceleration of bioremediation in the subsurface. Journal of Microbiological Methods 44, no. $3: 271-281$.

Mailloux, B. J., M. E. Fuller, T. C. Onstott, J. Hall, H. L. Dong, M. F. DeFlaun, S. H. Streger, R. K. Rothmel, M. Green, D. J. P. Swift, and J. Radke. 2003a. The role of physical, chemical, and microbial heterogeneity on the field-scale transport and attachment of bacteria. Water Resources Research 39, no. 6: 1142.

Mauilloux, B. J., M. E. Fuller, G. F. Rose, T. C. Onstott, M. F. DeFlaun, E. Alvarez, C. Hemingway, R. B. Hallet, T. J. Phelps, and T. Griffin. 2003b. Modular injection system, multilevel sampler, and manifold for tracer tests. Ground Water 41, no. 6: 816-827.

Mailloux, B. J. and M. E. Fuller. 2003. Determination of in situ bacterial growth rates in aquifers and aquifer sediments. Applied and Environmental Microbiology 69, no. 7: 3798-808. 
McKinley, J. P., J. M. Zachara, J. Wan, D. E. McCready, and S. M. Heald. 2007. Geochemical controls on contaminant uranium in vadose Hanford Formation sediments at the 200 Area and 300 Area, Hanford Site, Washington. Vadose Zone Journal 6, no. 4: 1004-1017.

Mills, A. L., J. S. Herman, G. M. Hornberger, and T. H. DeJesus. 1994. Effect of solution ionicstrength and iron coatings on mineral grains on the sorption of bacterial cells to quartz sand. Applied and Environmental Microbiology 60, no. 9: 3300-3306.

Mixon, R.B. 1985. Stratigraphic and geomorphic framework of the uppermost Cenozoic deposits in the Southern Delmarva Peninsula, Virginia and Maryland. U.S. Geological Survey, Professional Paper 1067-G.

Murphy, E. M. and T. R. Ginn. 2000. Modeling microbial processes in porous media. Hydrogeology Journal 8, no. 1: 142-158.

Musslewhite, C. L., M. J. Mclnerney, T. C. Onstott, H. Dong, M. Green-Blum, D. Swift, S. MacNaughton, D. C. White, C. J. Murray, and Y. Chien. 2003. The factors controlling microbial distribution and activity in the shallow subsurface. Geomicrobiology Journal 20, no. 3: 245-261.

Musslewhite, C. L., D. Swift, J. Gilpen, and M. J. Mclnerney. 2007. Spatial variability of sulfate reduction in a shallow aquifer. Environmental Microbiology 9, no. 11: 2810-2819.

Nelson, K. E. and T. R. Ginn. 2001. Theoretical investigation of bacterial chemotaxis in porous media. Langmuir 17, no. 18: 5636-5645.

Parsons, B., D. J. P. Swift, and K. Williams. 2003. Quaternary facies assemblages and their bounding surfaces, Chesapeake Bay Mouth: An approach to mesoscale stratigraphic analysis. Journal of Sedimentary Research 73, no. 5: 672-690. 
Pfiffner, S. M., A. V. Palumbo, B. L. Kinsall, A. D. Peacock, D. C. White, and T. J. Phelps. 2001. Microbial heterogeneity implications for bioremediation. In Innovative Methods in Support of Bioremediation, eds. V. Magar, T. Vogel, C. Aelion, and A. Leeson, 73-80. Columbus, OH: Battelle Press.

Rubin, Y. and S. S. Hubbard, eds. 2005. Hydrogeophysics, Water Science and Technology Library, vol. 50. Dordrecht: Springer.

Scheibe, T. D., Y.-J. Chien, and J. S. Radtke. 2001. Use of quantitative models to design microbial transport experiments in a sandy aquifer. Ground Water 39, no. 2: 210-222.

Scheibe, T. D. and Y.-J. Chien. 2003. An evaluation of conditioning data for solute transport prediction. Ground Water 41, no. 2: 128-141.

Scheibe, T. D. and B. D. Wood. 2003. A particle-based model of size or anion exclusion with application to microbial transport in porous media. Water Resources Research 39, no. 4: 1080.

Scheibe, T. D., Y. Fang, C. J. Murray, E. E. Roden, J. Chen, Y.-J. Chien, S. C. Brooks, and S. S. Hubbard. 2006. Transport and biogeochemical reaction of metals in a physically and chemically heterogeneous aquifer. Geosphere 2, no. 4: 220-235.

Scheibe, T. D., H. Dong, and Y. Xie. 2007. Correlation Between Bacterial Attachment Rate Coefficients and Hydraulic Conductivity and its Effect on Field-Scale Bacterial Transport. Advances in Water Resources 30, no. 6-7: 1571-1582.

Seeboonruang U. and T. R. Ginn. 2006a. Upscaling heterogeneity in aquifer reactivity via exposure-time concept: Forward model. Journal of Contaminant Hydrology 84, no. 3-4: 127-154. 
Seeboonruang U. and T. R. Ginn. 2006b. Upscaling heterogeneity in aquifer reactivity via the exposure-time concept: Inverse model. Journal of Contaminant Hydrology 84, no. 3-4: 155177.

Tobin K. J., T. C. Onstott, M. F. DeFlaun, F. S. Colwell, and J. Fredrickson. 1999. In situ imaging of microorganisms in geologic material. Journal of Microbiological Methods 37, no. 3: 201213.

Torkzaban, S., S. S. Tazehkand, S. L. Walker, and S. A. Bradford. 2008. Transport and fate of bacteria in porous media: Coupled effects of chemical conditions and pore space geometry. Water Resources Research 44, no. 4: W04403.

Weiss, T. H., A. L. Mills, G. M. Hornberger, and J. S. Herman. 1995. Effect of bacterial cell shape on transport of bacteria in porous media. Environmental Science \& Technology 29, no. 7: 1737-1740.

Wildung, R. D., S. W. Li, C. J. Murray, K. M Krupka, Y. Xie, N. J. Hess, and E. E. Roden. 2004. Technetium reduction in sediments of a shallow aquifer exhibiting dissimilatory iron reduction potential. FEMS Microbial Ecology 49, no. 1: 151-162.

Williams, K. H., A. Kemna, M. Wilkins, J. Druhan, E. Arntzen, L. N’Guessan, P. E. Long, S. S. Hubbard, and J. F. Banfield. 2009. Geophysical monitoring of microbial activity during stimulated subsurface bioremediation. Environmental Science and Technology, 43, no. 17: 6717-6723.

Wu, W. M., J. Carley, M. Fienen, T. Mehlhorn, K. Lowe, J. Nyman, J. Luo, M. E. Gentile, R. Rajan, D. Wagner, R. F. Hickey, B. H. Gu, D. Watson, O. A. Cirpka, P. K. Kitanidis, P. M. Jardine, and C. S. Criddle. 2006a. Pilot-scale in situ bioremediation of uranium in a highly contaminated 
aquifer. 1. Conditioning of a treatment zone. Environmental Science \& Technology 40, no. 12: $3978-3985$.

Wu, W. M., J. Carley, T. Gentry, M. A. Ginder-Vogel, M. Fienen, T. Mehlhorn, H. Yann, S. Caroll, M. N. Pace, J. Nyman, J. Luo, M. E. Gentile, M. W. Fields, R. F. Hickey, B. H. Gu, D. Watson, O. A. Cirpka, J. Z. Zhou, S. Fendorf, P. K. Kitanidis, P. M. Jardine, and C. S. Criddle. 2006b. Pilot-scale in situ bioremediation of uranium in a highly contaminated aquifer. 2. Reduction of $\mathrm{U}(\mathrm{VI})$ and geochemical control of $\mathrm{U}(\mathrm{VI})$ bioavailability. Environmental Science \& Technology 40, no. 12: 3986-3995.

Zhang C. L., R. M. Lehman, S. M. Pfiffner, S. P. Scarborough, A. V. Palumbo, T. J. Phelps, J. J. Beauchamp, and F. S. Colwell. 1997. Spatial and temporal variations of microbial properties at different scales in shallow subsurface sediments. Applied Biochemistry and Biotechnology - Part A Enzyme Engineering and Biotechnology 63-65, no. 1-3: 797-808.

Zhang, C., A. V. Palumbo, T. J. Phelps, J. J. Beauchamp, F. J. Brockman, C. J. Murray, B. S. Parsons, and D. J. P. Swift. 1998. Grain-size and depth constraints on microbial variability in coastal plain subsurface sediments. Geomicrobiology Journal 15, no. 3: 171-185.

Zhang, P., W. P. Johnson, and R. Rowland. 1999. Bacterial tracking using ferrographic separation. Environmental Science \& Technology 33, no. 14: 2456-2460.

Zhang, P., W. P. Johnson, T. D. Scheibe, K.-H. Choi, F. C. Dobbs, and B. J. Mailloux. 2001. Extended tailing of bacteria following breakthrough at the Narrow Channel Focus Area, Oyster, Virginia. Water Resources Research 37, no. 11: 2687-2698. 
Zhou, J., B. Xia, H. Huang, A. V. Palumbo, and J. M. Tiedje. 2004. Microbial diversity and heterogeneity in sandy subsurface soils. Applied and Environmental Microbiology 70, no. 3: 1723-1734. 


\section{Acknowledgments}

The research reported herein was supported by the U. S. Department of Energy (DOE), Office of Biological and Environmental Research, Natural and Accelerated BioRemediation (NABIR) Program (predecessor of the current DOE Subsurface Biogeochemical Research program), Contract No. DE-AC0205CH11231. The authors would like to acknowledge the leadership of Frank Wobber, the program manager for the Acceleration element of NABIR at the time the research was performed. Access to the field site was generously granted by The Nature Conservancy, Virginia Coast Reserve. The authors thank John McCray and two anonymous reviewers for their thoughtful comments and suggestions. Special thanks are due to our many colleagues who participated in the South Oyster Site project, and whose hard work is reflected in the body of research summarized here. 
Figure 1

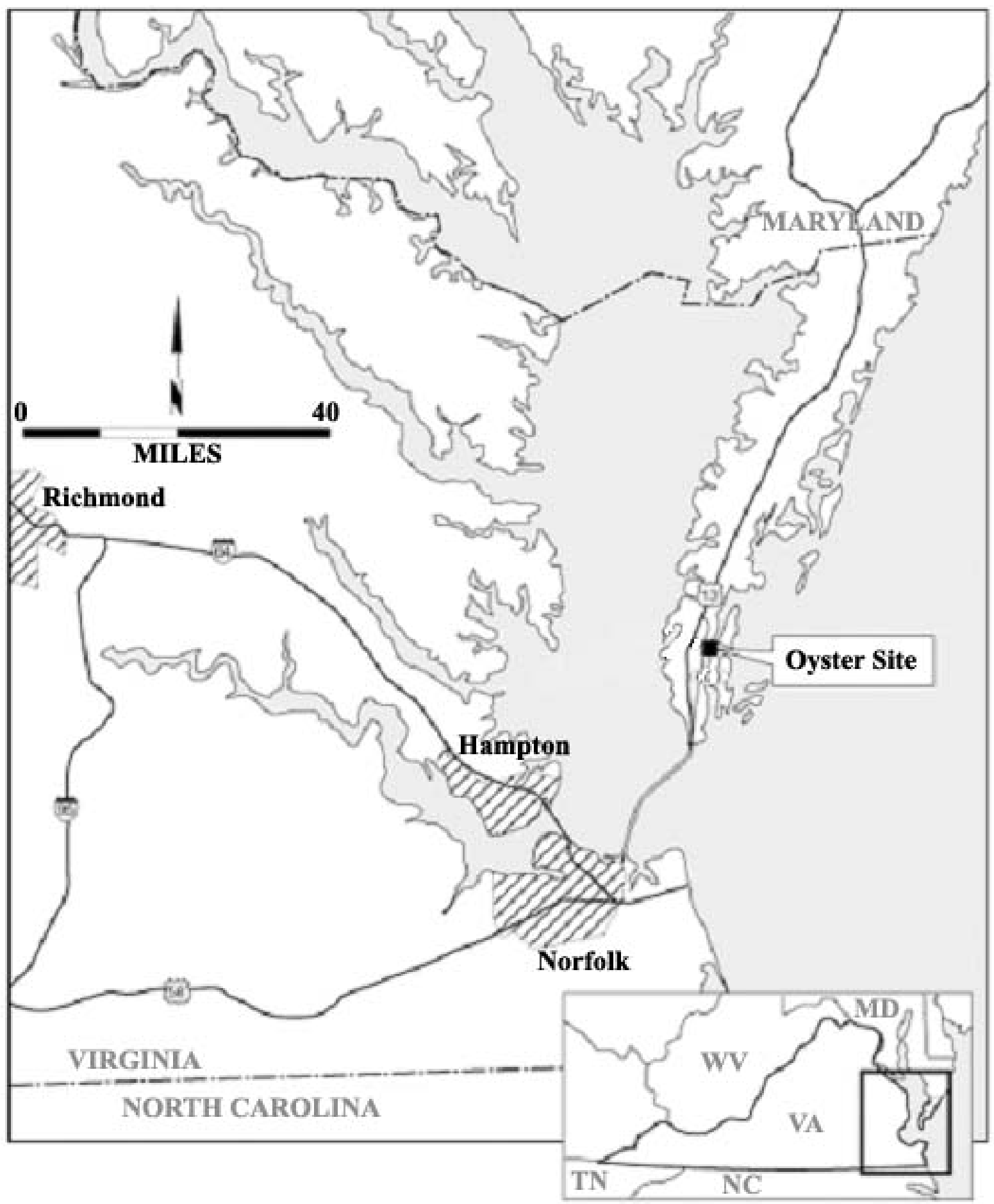

Figure 1. Location map of the South Oyster Site (from Scheibe and Chien, 2003) 
Figure 2

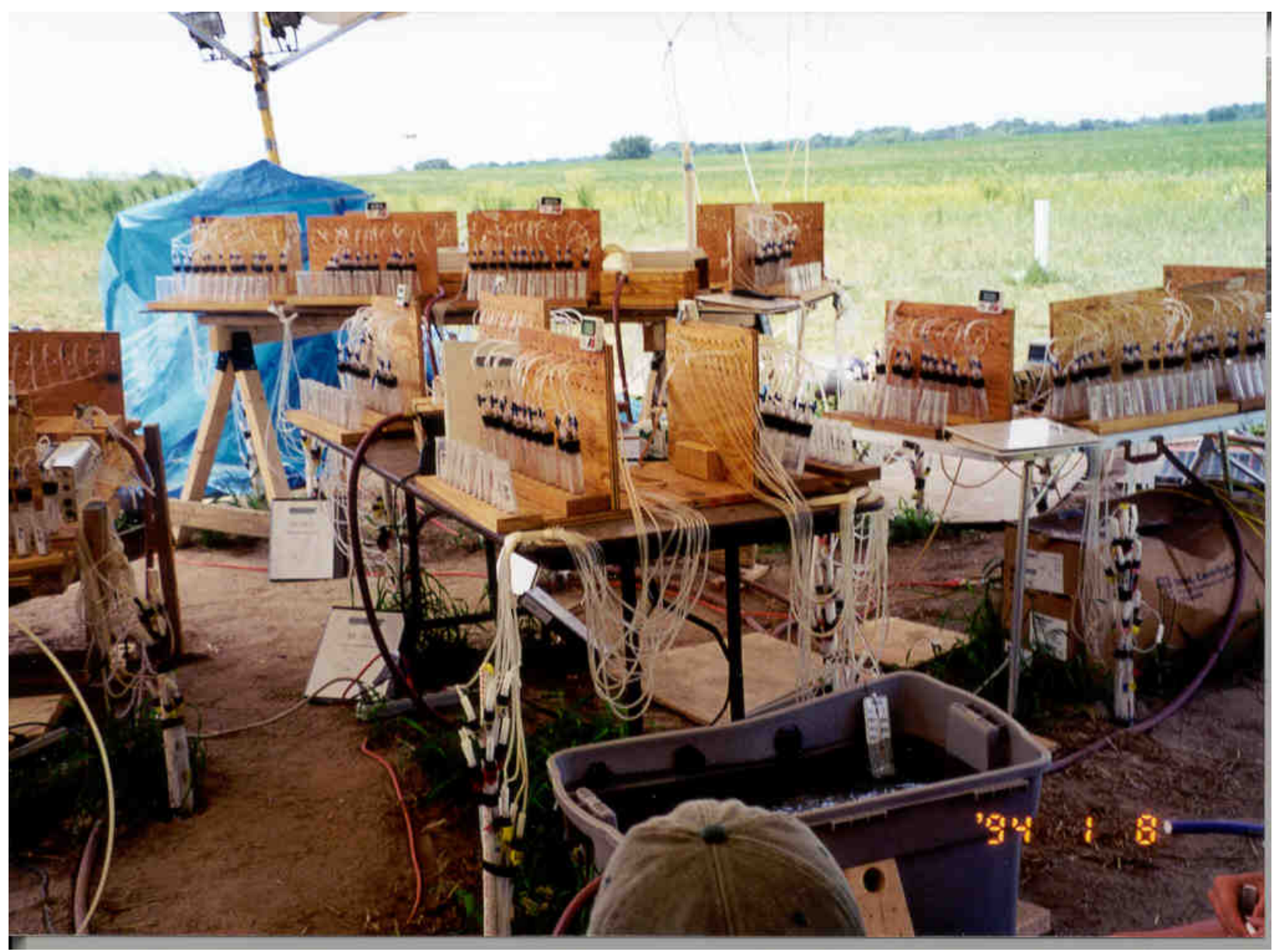

Figure 2. Photograph of the multi-level sampling stations and other instrumentation at the Narrow Channel flow cell during an injection experiment. (Note: Time stamp on the photograph is incorrect; photograph was taken in summer 1999). Photograph by Mary

\section{DeFlaun.}


Figure 3

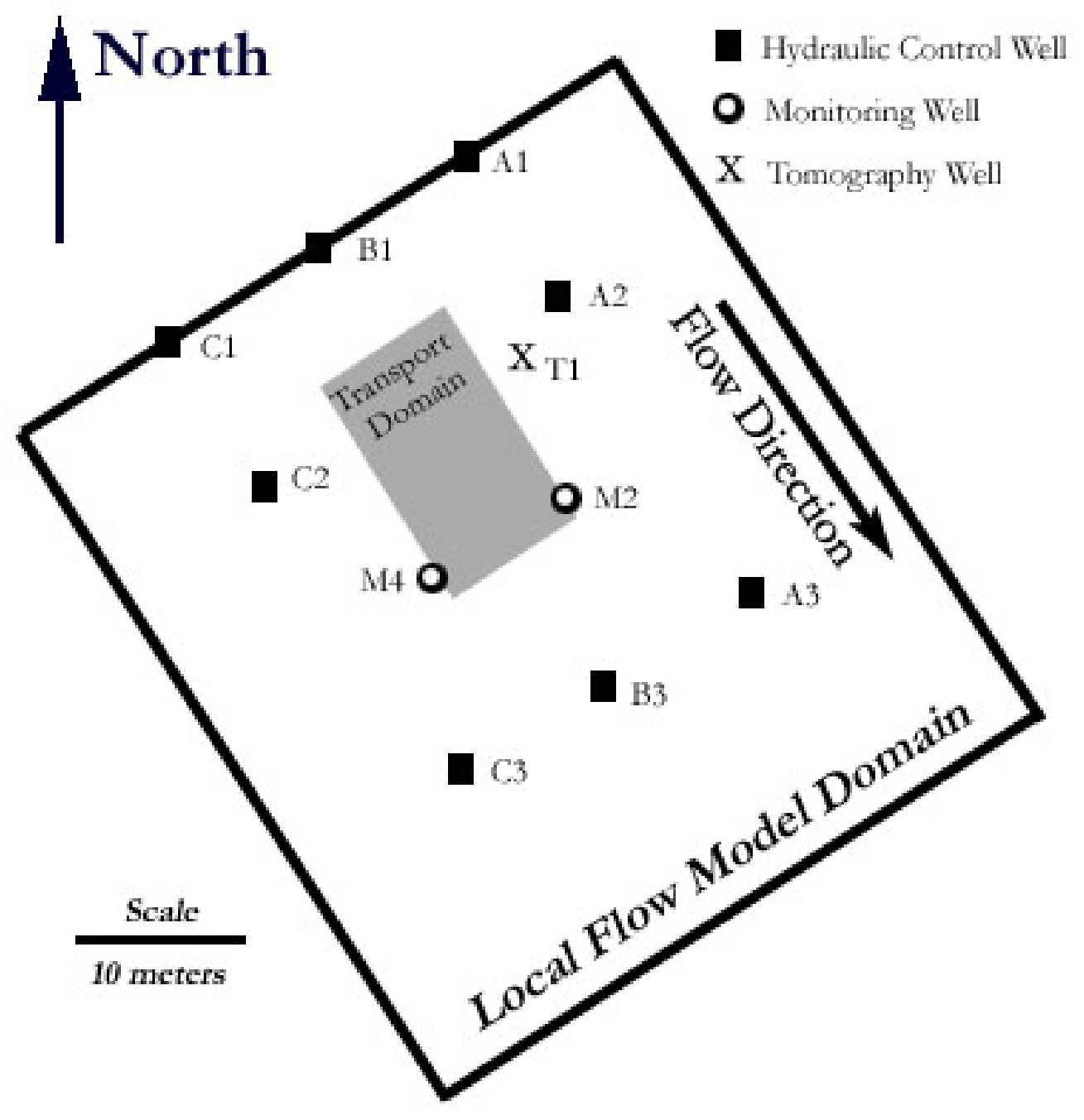

Figure 3a. Local flow model domain for the NC focus area, indicating the locations of hydraulic control and monitoring wells as well as the extent of the transport model domain (see Figure 3b). From Scheibe and Chien (2003) 


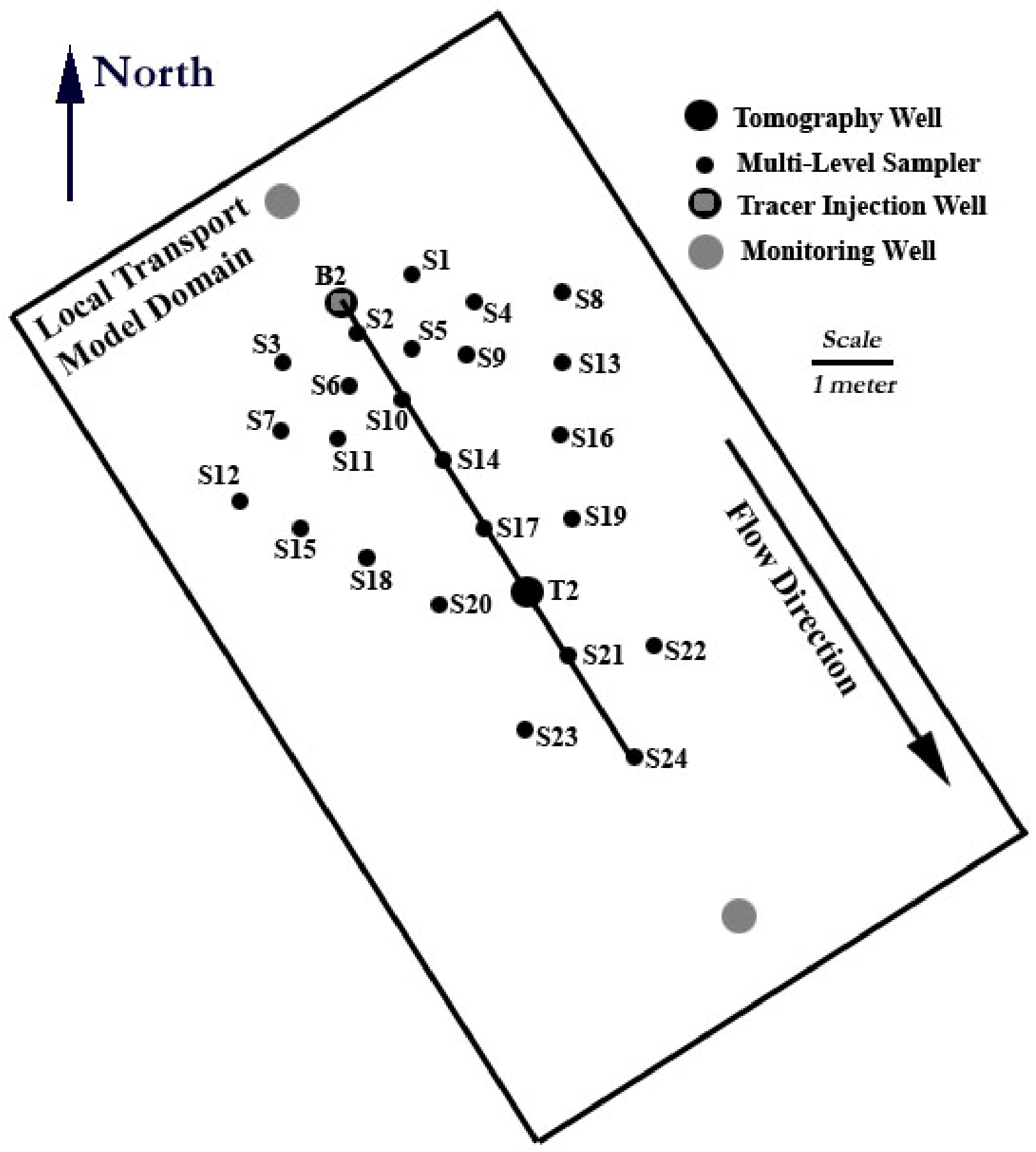


Figure 3b. Expanded view of the local transport model domain, showing locations of injection well (B2) and multi-level sampling wells (S1-S24) as well as two monitoring wells (M1 and M3) that fall within the local transport domain. Refer to Figure 3a for the location of the local transport model domain within the local flow model domain. Solid line down center of flow cell indicates location of tomography cross-section shown in Figure 4. Modified from Scheibe and Chien (2003). 
a)

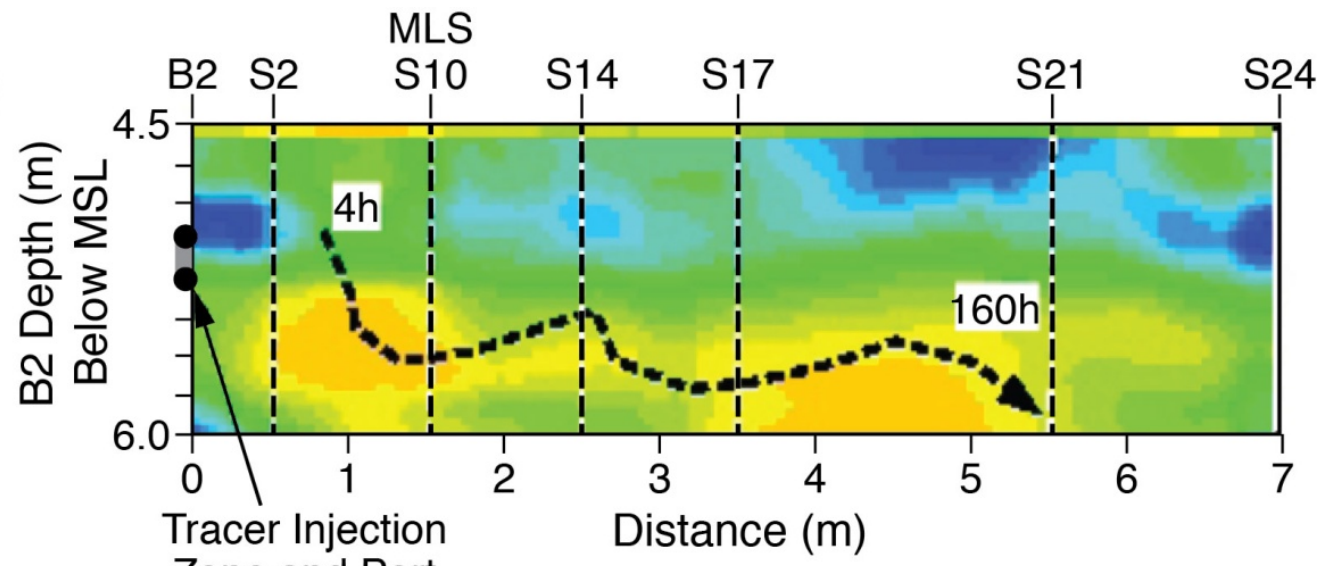

Zone and Port

Locations

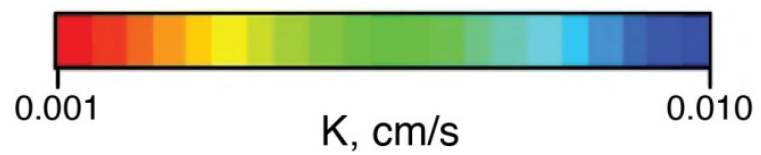

b)

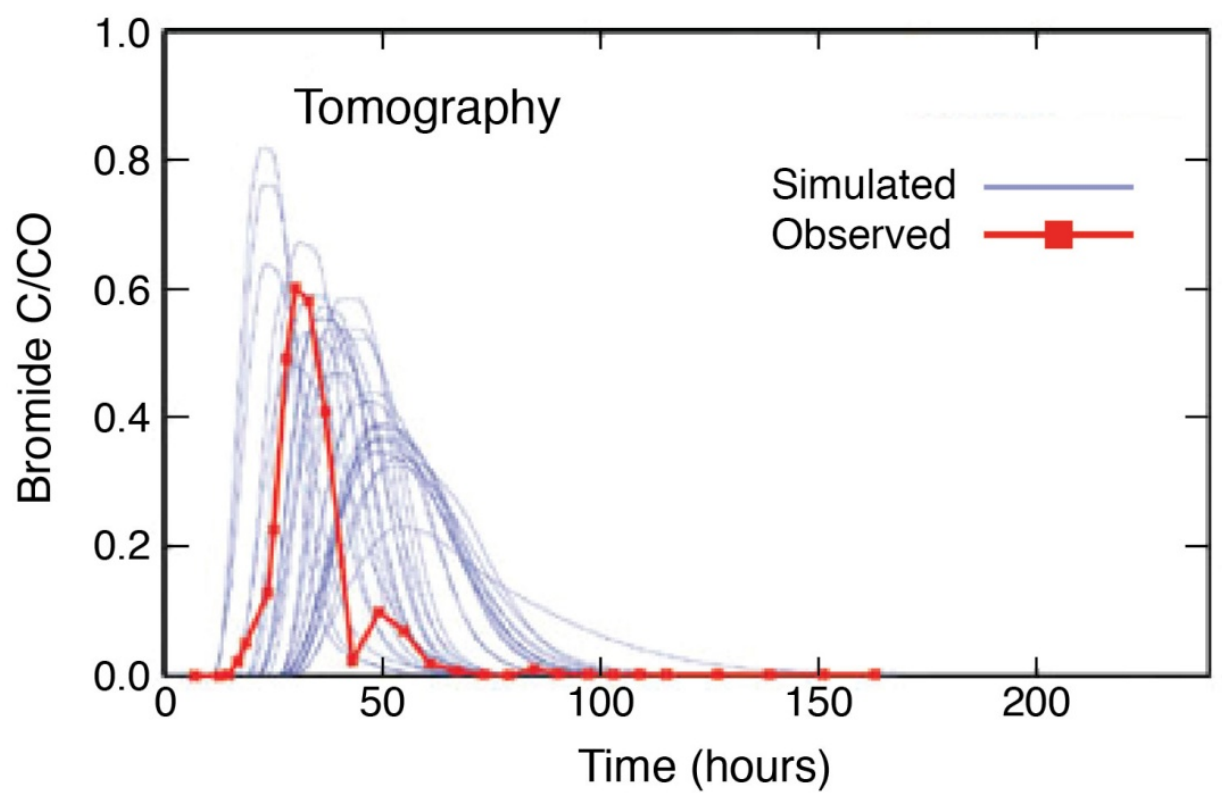

ESD11-002

Figure 4. (a) Estimates of hydraulic conductivity mean values along flow cell centerline obtained through integration of crosshole radar tomographic velocity and wellbore flowmeter data. Superimposed on top of the hydraulic conductivity estimates is the trajectory of the bromide tracer plume centroid over time, calculated using the 
breakthrough data (modified from Hubbard et al., 2001). (b) Comparison of measured bromide breakthrough at MLS S10 with simulated realizations of breakthrough based on a numerical aquifer model conditioned to the tomographic estimates of hydraulic conductivity such as those shown in (a) (modified from Scheibe et al., 2001). The location of the geophysical traverse and MLS well are highlighted in Figure 3b. 

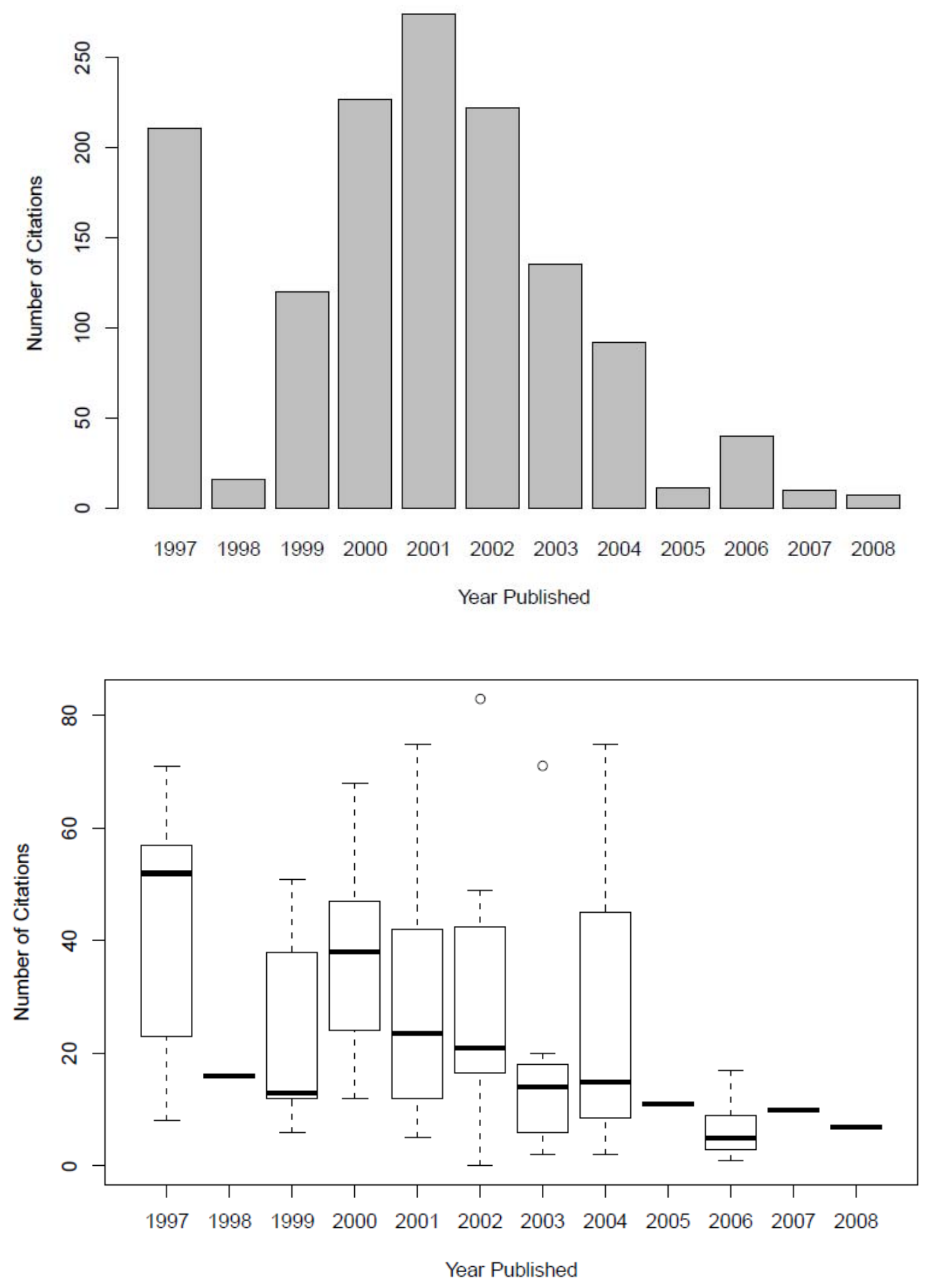

Figure 5. Statistical summary of citation statistics for papers listed in Table 2. Top: Total citations to papers published in each year. Note: 1997 spike reflects papers related to the 59 
preliminary study reported in DeFlaun et al. 1997. Bottom: Box plots of citation statistics for papers published in each year. Dark line is the median number of citations per paper, and the outer ends of the boxes represent the $25^{\text {th }}$ and $75^{\text {th }}$ percentiles of the distribution for that year. 


\section{DISCLAIMER}

This document was prepared as an account of work sponsored by the United States Government. While this document is believed to contain correct information, neither the United States Government nor any agency thereof, nor The Regents of the University of California, nor any of their employees, makes any warranty, express or implied, or assumes any legal responsibility for the accuracy, completeness, or usefulness of any information, apparatus, product, or process disclosed, or represents that its use would not infringe privately owned rights. Reference herein to any specific commercial product, process, or service by its trade name, trademark, manufacturer, or otherwise, does not necessarily constitute or imply its endorsement, recommendation, or favoring by the United States Government or any agency thereof, or The Regents of the University of California. The views and opinions of authors expressed herein do not necessarily state or reflect those of the United States Government or any agency thereof or The Regents of the University of California.

Ernest Orlando Lawrence Berkeley National Laboratory is an equal opportunity employer. 